\title{
Political Cycles in OECD Economies
}

\section{Citation}

Alesina, Alberto, and Nouriel Roubini. 1992. Political cycles in OECD economies. Review of Economic Studies 59(4): 663-688.

\section{Published Version}

http://dx.doi.org/10.2307/2297992

\section{Permanent link}

http://nrs.harvard.edu/urn-3:HUL.InstRepos:4553025

\section{Terms of Use}

This article was downloaded from Harvard University's DASH repository, and is made available under the terms and conditions applicable to Other Posted Material, as set forth at http:// nrs.harvard.edu/urn-3:HUL.InstRepos:dash.current.terms-of-use\#LAA

\section{Share Your Story}

The Harvard community has made this article openly available.

Please share how this access benefits you. Submit a story.

Accessibility 
NBER WORKING PAPERS SERTES

POLTTICAL CYCLES IN OECD ECONOMIIES

Alberto Alesina

Nouriel Roubini

Working Paper No. 3478

NATIONAL BUREAU OF EOONOMIC RESEAROH 1050 Massachusetts Avemue

Cambridge, MA 02138

October 1990

We thank James Hamilton for generously sharing his camputer programs, Benjamin Friedman, Sule Ozler, Torsten Persson, Dani Rodrick, James Stock, Philippe Weil and participants of seminars at Carnegie-Mellon, Harvard, MIIT, North Carolina, Trade Union Institute in Stockholm, and NBER Summer Institute for very helpful camments on earlier drafts. The suggestions of our discussant, Assar Iindbeck, and of many other conference participants were extremely valuable. Gerald cohen provided excellent research assistance. This paper was written while Alesina was an Olin Fellow at the NBER; he gratefully acknowledges financial support from the olin and sloan Foundations. This paper is part of NBER's research program in International Studies. Any opinions expressed are those of the authors and not those of the National Bureau of Economic Research. 
NBER Working Paper \#3478

Octaber 1990

\section{POLTIICAL CYCLES IN OECD EOONOMIES}

\section{ABSTRACT}

This paper studies whether the dymamic behavior of GNP growth, unemployment and inflation is systematically affected by the timing of elections and of changes of goverments. The sample includes the last three decades in 18 OECD economies. We explicitly test the implication of several models of political cycles, both of the "opportunistic" and of the "partisan" type. Also, we confront the implication of recent "rational" models with more traditional approaches. our results can be summarized as follows: a) The "political business cycle" hypothesis, as formulated in Nordhaus (1975) on output and unemployment is generally rejected by the data. With the exception of Japan, we also reject by the extension of the "political business cycle" model, with endogenous timing of elections; b) inflation tends to increase immediately after elections, perhaps as a result of preelectoral expansionary monetary and fiscal policies; (c) we find evidence of temporary partisan differences in output and unemployment and of long-rum partisan differences in the inflation rate as implied by the "rational partisan theory" by Alesina (1987): (d) we find virtually no evidence of permanent partisan differences in output and unemployment.

Alberto Alesina Department of Economics Harvard University Cambridge, MA 02138 NBER and CEPR
Nouriel Roubini

Department of Econamics Box 1972 - Yale Station Yale University

New Haven, CT 06520-1972 NBER and CEPR 


\section{Introduction}

Different models of political cycles emphasize either the "opportunistic" or the "partisan" incentives of policymakers. In "opportunistic" models, the policymakers maximize their popularity or their probability of reelection. In "partisan" models different political parties represent the interests of different constituencies and, when in office, follow policies which are favorable to their supporting groups; specifically, the left wing parties are more concerned with the problem of unemployment, while the right wing parties are relatively more willing to bear the costs of unemployment to reduce inflation.

This literature has developed in two clearly distinct phases. The first one, in the mid-seventies, is due to the influential work by Nordhaus (1975), and Lindbeck (1976) on "opportunistic" cycles and by Hibbs (1977) on "partisan" cycles. These papers share a "pre-rational expectations" model of the economy and are based upon an exploitable "Phillips curve". The "political business cycle" model of Nordhaus predicts pre-electoral fast growth and low unemployment; raising inflation around the election time and a post-electoral recession, regardless of the political orientation of the incumbent. Hibbs' partisan model implies systematic and permanent differences in the inflation/unemployment combination chosen by different political parties.

Macroeconomists soon lost interest in this subject, because at that time the profession was developing (or fighting against), the "rational expectations revolution." 1

The second phase took off in the mid-eighties as a branch of the gametheoretic approach to the positive theory of policy. Cukierman and Meltzer (1986), Rogoff and Sibert (1988), Rogoff (1990), and Persson and Tabellini (1990) propose rational "opportunistic" models; Alesina (1987) develops a 
rational partisan approach. These models depart from their predecessors in two important dimensions. First, the assumption of economic agents' rationality makes real economic activity less directly and predictably influenced by monetary policy. Second, voters' rationality implies that they cannot be systematically "fooled" in equilibrium.

This second generation of models has empirical implications which are quite different from those of the earlier literature: the assumption of rationality reduces the extent and the likelihood of regular political cycles, although it does not eliminate them. For example, in models with rational economic agents and voters, Nordhaus' type cycles are mitigated. Rather than regular multi-year cycles on output and unemployment, one should observe, according for instance to Rogoff and Sibert (1988), short-lived electoral cycles on monetary and fiscal policy instruments, but not necessarily on economic activity outcomes. Alesina (1987, 1988b) shows that in a partisan model with nominal wage contracts and rational voters, permanently different inflation rates across parties may result only in temporary, post-election differences in output and unemployment.

Finally, Ito (1990a,b) and Terrones (1989) study political business cycles with endogenous timing of elections, an institutional setting which is very common in parliamentary democracies.

This paper addresses two questions. First, whether or not the dynamic behavior of GNP growth, unemployment and inflation is systematically affected by the timing of elections and of changes of governments. Second, whether or not the second generation of rational models has provided useful insights to interpret the evidence. The paper suggests an affirmative answer to both these questions by examining 18 OECD democracies, in the last three decades. 
3

Our results can be summarized as follows: a) The "political business cycle" hypothesis, as formulated in Nordhaus on output and unemployment is generally rejected by the data. (Some favorable evidence can be found in only two countries.) In every country, with the exception of Japan, we also reject the extension of the "political business cycle" model, with endogenous timing of elections; b) inflation tends to increase immediately after elections, perhaps as a result of pre-electoral expansionary monetary and fiscal policies; if confirmed by direct evidence on policy. instruments, this result yields support to the Rogoff and Sibert (1988) and Rogoff (1990) model of "political budget cycles"; (c) we find evidence of temporary partisan differences in output and unemployment and of long-run partisan differences in the inflation rate as implied by the "rational partisan theory" of Alesina (1987). This pattern appears rather unambiguously in countries with a pure two-party system, or with clearly identifiable "right" and "left" coalitions; (d) we find virtually no evidence of permanent partisan differences in output and unemployment. Indirectly, results (c) and (d) yield some support to the positive model of inflation developed by Kydland-Prescott (1977) and Barro and Gordon $(1983 a, b)$.

The qualitative features of these results are consistent with the finding on the United States by Alesina and Sachs (1988), Alesina (1988a) and Chapell and Keech (1988). The advantage of a multi-country study is that, of course, one has many more degrees of freedom. Elections and changes of governments are relatively infrequent events. Thus, the researcher is left with very few observations and only one country is considered. This is why systematic multi-country studies are particularly useful in this area. 
The paper is organized as follows. In the next section we highlight the empirical implications of several models of political cycles. Since several comprehensive reviews of the literature have recently appeared (Alesina (1988a), Nordhaus (1989), Persson and Tabellini (1990)) we sketch the various models very succinctly. In Section 3 we present regressions on a panel data set of all the countries in the sample. Section 4 discusses the results of country by country regressions. Section 5 checks the robustness of our results by employing Hamilton's (1989) method of timing recessions and expansions. Section 6 considers the issue of endogenous timing of elections. The last section concludes.

2. Models of Politico-Economic Cycles

\subsection{The "Political Business Cycle" (Nordhaus (1975))}

The assumptions underlying Nordhaus' "political business cycle" (henceforth $P B C$ ) can be characterized as follows:

A.1) The economy is described by a Phillips curve:

$$
\mathrm{y}_{t}-\alpha \mathrm{y}_{t-1}+\gamma\left(\pi_{t}-\pi_{t}^{\mathrm{e}}\right)+\varepsilon_{t} ; 0<\alpha<1 ; \gamma>0 \text {. }
$$

where $y$ is output growth; $\pi$ is inflation; $\pi^{e}$ is expected inflation; $\varepsilon$ is a random shock with zero mean; $\alpha, \gamma$ are parameters. ${ }^{2}$ The autoregressive term in (1) captures various sources of persistence. The "natural" steady state level of growth is normalized at zero, with no loss of generality.

A.2) Inflation expectations are adaptive:

$$
\pi_{t}^{\mathbf{e}}=\pi_{t-1}+\lambda\left(\pi_{t-1}^{\mathbf{e}}-\pi_{t-1}\right) ; \quad 0<\lambda<1
$$

A.3) Inflation is directly controlled by the policymakers. 3 
A.4) Politicians are "opportunistic": they only care about holding office, and they do not have "partisan" objectives.

A.5) Voters are "retrospective." They judge the incumbent's performance based upon output growth and inflation during the incumbents' term of office, and heavily discount past observations.

A.6) The timing of elections is exogenously fixed.

Under these assumptions, Nordhaus derives the following testable implications: (i) every government follows the same policy; (11) towards the end of his term of office, the incumbent stimulates the economy to take advantage of the "short run" more favorable Phillips curve; (iii) the rate of inflation increases around the election time as a result of the pre-electoral economic expansion; after the election, inflation is reduced with contractionary policies. ${ }^{4}$

This basic model has recently been developed in two directions: first by investigating the role of rationality and second the role of endogenous timing of the elections. These two extensions are illustrated below.

\subsection{Rational Political Business Cycle Models}

Persson and Tabellini (1990) propose a simple model which sumarizes the basic insights of this approach, due to Rogoff and Sibert (1988). Assumptions A.1, A.3, A.4, and A.6 as in Nordhaus are retained. Assumption A.2 is replaced by:

A. $\left.2^{\prime}\right) \quad \pi_{t}^{e}-E\left(\pi_{t} / I_{t-1}\right):$ rational expectations

A. ' ') $I_{t-1}$ includes all the relevant information except the level of "competence" of different policymakers. 
Assumption A. 5 is substituted by:

A. 5') Voters choose the candidate which is rationally expected to deliver the highest utility, if elected.

A. 5'') There are no differences in voters' utility functions.

$E(\cdot)$ is the expectation operator and $I_{t-1}$ is the information set of the voters at time $(t-1)$ when expectations are formed. A.2'') implies an asymmetry of information between the policymakers and the voters: the former know their own competence, but the latter do not. 5 . Policymakers" "competence" is defined as their ability of keeping unemployment low with a relatively low level of inflation. 6

By taking advantage of this informational asymmetry, and by trying to appear as competent as possible before elections, politicians behave in a way leading to a Nordhaus' type PBC. However, given voters' rationality and awareness of politicians' incentives, the latter are limited in their "opportunistic" behavior. Thus, the resulting cycles are more short lived and less regular than in Nordhaus' model.

The original proponents of the "competence" model, i.e. Rogoff and Sibert (1988) and Rogoff (1990), consider a budget problem, rather than an inflation/unemployment trade-off, but with identical assumptions about the distribution of information. These papers have empirical implications on opportunistic cycles on monetary and fiscal variables, rather than on unemployment and output. In fact, the model by Rogoff and sibert (1988) has implications on the inflation rate similar to those of Nordhaus' model, but does not imply any correlation between elections and output or unemployment. 


\subsection{Endogenous Elections}

Ito $(1990 \mathrm{a}, \mathrm{b})$ and Terrones (1989) remove assumption A.6: the latter extends Rogoff's (1990) model, while Ito (1990a,b) presents a simpler model in which while the policymakers are strategic in choosing the timing of elections, the voters follow rules of thumb in their voting behavior. That is, Ito maintains A.5, while Terrones adopts A.5' and A.5''. These papers suggest that early elections are called to capitalize on good economic conditions. Thus, the better the state of the economy, the sooner elections are called.

Using Ito's simple and very insightful framework, suppose that the government has no control on real economic activity and that voters' behavior is described by A.5. Then, if high growth occurs soon after an election, the incumbent may choose to call another election; if, instead, growth is low, he waits: he has a good chance of capitalizing on a high growth period by calling an election later in his term of office. However, as time elapses from the previous election, the date at which an election has to be called according to the law approaches. Then, even an average level of growth may trigger an election; this is because the incumbent wants to avoid the risk of reaching the last period with low growth. Thus, the probability that an election is called should be an increasing function of the time elapsed from the previous election and of the state of the economy.

2.4 The "Partisan Theory"; Hibbs (1977), (1987)

A strong version of the "partisan theory" (henceforth PT) based upon a non-rational expectation mechanism, adopts assumptions A.1, A.2, A. 3 and A.6. Assumptions A. 4 and A. 5 are substituted by: 
A.4') Politicians are "partisan," in the sense that different parties maximize different objective functions. Left wing parties attribute a higher cost to unemployment relative to inflation than right wing parties.

A. ' $^{\prime}$ ) Each voter is aware of the partisan difference and votes for the party which offers the most preferred policy.

The assumption of partisanship is justified by the distributional consequences of unemployment. In periods of high (low) unemployment, low (high) growth and low inflation the relative share of income of the upper middle class, increases (decreases). On this point, see Hibbs (1987).

Not surprisingly, this model implies that different parties choose different points on the Phillips curve: output growth and inflation should be permanently higher and unemployment permanently lower when the left is in office than with right wing governments. 7

\section{5 "Rational Partisan Theory" (Alesina (1987))}

Alesina (1987) and (1988b) suggest a "rational partisan theory" (henceforth RPT). This model adopts assumption A.1, A.2', A.3, A.4', A.5',' and A.6. The objective functions of the two parties can be written as:

$$
w^{i}-\sum_{t=0}^{T} \delta^{t}\left[-\left(\pi_{t}-c^{i}\right)^{2}-b^{i}\left(y_{t}-k^{i}\right)^{2}\right] \quad 0<\delta<1
$$

where $i-L, R$ identifies the "left" and the "right" parties. The difference between the two parties can be summarized by at least one of these three sets of inequalities:

$$
c^{L}>c^{R} \geq 0 ; \quad b^{L}>b^{R} \geq 0 ; \quad K^{L}>k^{R} \geq 0
$$


The last double inequality implies the time-inconsistency problem in monetary policy pointed out by Kydland-Prescott (1977) and Barro and Gordon (1983a,b). Since at least one of the two parties targets a level of output growth which is above the natural rate (normalized at zero), it introduces an "inflation bias" because of the lack of precommitments in monetary policy. Thus, a test of the RPT is indirectly a test for this specification of policymakers' objective functions.

This model generates a political cycle if we assume that uncontingent labor contracts are signed at discrete intervals (which do not coincide with the political terms of office) and that electoral outcomes are uncertain because of shocks to voters' preferences or to voters' participation rates in elections. The basic ldea of the model is that, given the sluggishness in wage adjustments, changes in the inflation rate associated with changes in government create temporary deviations of real economic activity from its natural level.

More specifically, the following testable implications can be derived from the model: (i) at the beginning of a right wing (left wing) government output growth is below (above) its natural level and unemployment is above (below); (ii) after expectations, prices and wages adjust, output and unemployment return to their natural level; after this adjustment period, the level of economic activity should be independent of the party in office; (iii) the rate of inflation should remain higher throughout the term of a left wing government; note that this occurs even if $c^{L}=c^{R}$ in (3), as long as $\mathrm{K}^{\mathrm{L}}>\mathrm{K}^{\mathrm{R}}$ or $\mathrm{b}^{\mathrm{L}}>\mathrm{b}^{\mathrm{R}}$. That is, the time consistent (but sub-optimal) inflation rate remains higher for left wing parties even after the level of economic activity returns to its natural level. 
2.6 Previous Empirical Results

Most of the empirical studies on political cycles use post-war United States data. The evidence in favor of the RPT is relatively strong; evidence of "opportunistic" PBC is found for certain policy instruments (particularly government transfers) for limited sub-samples: for recent surveys of this empirical literature see Alesina (1988a) and Nordhaus (1989).

Multi-country studies are more scarce. Alt (1985) is the first one to formally test for partisan patterns in unemployment in twelve OECD democracies and finds evidence quite consistent with this approach. Paldam (1979) finds very weak evidence (if any at all) of Nordhaus' political business cycle on output and unemployment using a sample of seventeen OECD countries. The same author (1989a,b) finds stronger evidence of partisan effects using annual data. Alesina (1989) provides some qualitative tests with annual data using the same sample of countries; his results suggest that the RPT is broadly consistent with the evidence while the same paper does not find clear evidence of PBC on growth and unemployment. Alvarez, Garrett and Lange (1989) suggest that the degree of success of "partisan policies" may depend upon the characteristics of labor market institutions and of unions' behavior. On the contrary, Sheffrin (1989) finds inconclusive results for the RPT. However, Sheffrin's definition of "unexpected change" of governments is questionable . That paper disregards the fact that in several countries the same party or coalition was elected repeatedly with no electoral uncertainty. (See Alesina (1990))

The contribution of the present paper is that, unlike its predecessors, it considers all the different theories, including models with endogenous elections, in a unified framework. Furthermore, unlike the recent work by 
Alesina and Paldam, we use quarterly data rather than annual data and make use of different and more robust statistical tests. The use of quarterly data is quite important since the precise timing of cyclical fluctuations in relation to elections and changes in political regime is crucial for the theories.

\section{Panel Regressions}

\subsection{Data}

We consider all the OECD countries which have been democracies in the sample period considered, which is 1960 to 1987 . The extent of the sample is limited by availability of quarterly data; in fact, for some countries not all the series are available even for this period. The countries included are: Australia, Austria, Belgium, Canada, Denmark, Finland, France, Germany, Japan, Ireland, Italy, the Netherlands, New Zealand, Norway, Sweden, Switzerland, United Kingdom, and the United States.

The economic data are quarterly observations on inflation, output growth, and unemployment. Inflation is defined as the yearly rate of change of the CPI from IMF, IFS. Output growth is obtained as the rate of change of real GNP (or GDP), also from IMF, IFS. For unemployment, we use the total standardized unemployment rate from OECD. More details on country specific data issues can be found in Table A-1 in Appendix. The political data are election dates, the dates of changes of governments, and the political orientation of various governments. This information is summarized in Table A-2. Dates of regime changes and elections do not always coincide in parliamentary systems in which changes of coalitions take place not only after elections. Sources for these political data are Alt (1985) and Banks (1987). The identification of changes of political orientation of governments is 
usually unambiguous. Whenever ambiguities occurred in the case of large coalition governments, we followed Alt's and Banks' conventions. It should be noted the countries for which positive results for the partisan theory are found, are those in which there are no ambiguities about the classification of government political orientation.

\subsection{Specification of Empirical Tests}

The most direct way of testing the various theories is to run the following panel regressions of time-series cross-section data, for instance on output growth:

$$
y_{t}-\alpha_{0}+\alpha_{1} y_{t-1}+\alpha_{2} y_{t-2} \ldots \alpha_{n} y_{t-n}+\alpha_{n+1} P_{t}+\varepsilon_{t}
$$

$y_{t}$ is the stacked vector of time-series data on output growth for the countries in the sample and PDUM is a political dumny which captures the implications of the different theories. The autoregressive specification for the dependent variable is chosen as the "best" using standard techniques. Similar regressions have been performed by McCallum (1978), Hibbs (1987), Alesina and Sachs (1988) and Alesina (1988a) on U.S. data. These tests are based upon the assumption that output growth and unemployment are generated by a covariance-stationary stochastic process that can be expressed in autoregressive form as in (5).

Since the sample includes open economies (most of which are "small"), we must control for the effect of the world economy on domestic economies, for two reasons. First, the "partisan" or opportunistic goals of the politicians are likely to be defined, in small open economies, in relation to the rest of the world. Second, regardless of the governments' goals, international trade 
and financial linkages make OECD economies highly interdependent.

We have followed two approaches to capture these effects. The first one is to redefine each country's variable as a difference between the actual variable and a proxy for the OECD average of the same variable. The second one is to add as a regressor in eq. (5) a proxy for a world or OECD average. Our results concerning the relative performance of various political models are insensitive to the procedure used. As an indicator of an OECD average of each economic variable we consider the average of the seven largest economies in our sample, which are the USA, Japan, Germany, France, the UK, Italy, and Canada, weighted by each country's share of GNP over the total. 8

In the remainder of this section we present results of panel regressions on the different political theories of the business cycle. We make use of a fixed effect model with constant slopes. By doing so we take into account differences in long-term growth rates, unemployment, and inflation across countries but we assume that the other parameters of the model are constant and equal across countries. ${ }^{9}$

\subsection{The "Rational Partisan Theory" (RPT)}

The political dummy used is:

$$
\text { DRPTN }- \begin{cases}+1 & \text { in the } N \text { quarters starting with that of } \\ -1 & \text { a change of government toward the right } \\ & \text { in the } N \text { quarters starting with that of } \\ & \text { a change of government toward the left } \\ & \text { otherwise }\end{cases}
$$

We tested the cases of $\mathrm{N}-4,6,8$. This choice of number of quarters is consistent with a wage contract model in which contracts have an average length of 1 or 2 years. 
Note that the variable DRPTN assumes values different from zero only following actual changes of governments, but not after every election if the same government is reappointed. According to the RPT theory, inflation surprises and thus output fluctuations may occur even if an incumbent is reappointed unexpectedly (Alesina, 1987). However, for long periods of time in many countries in the sample certain parties repeatedly won elections with virtually no political uncertainty. Furthermore, in countries with endogenous timing of elections, which are the large majority of the sample (see Table A2), in every period there is at least "some" probability that an election is called and that a change of government may occur. 10 In addition, in parliamentary systems sometimes government changes occur in the middle of a term, with no elections. Rather than trying to estimate the degree of political uncertainty in every period, which would be rather difficult if not impossible, we have chosen to estimate a somewhat weaker form of RPT, testing for temporary effects on real variables after actual changes of governments. An additional reason for doing so, is that several macroeconomic models in the "neo-Keynesian" tradition, imply that not only unexpected, but also expected aggregate demand policy may have some real effects. Thus, according to these approaches, stronger effects should found after actual changes of governments, with actual changes of policies, relative to the case of reappointment of the same government.

Column (1) of Table 1 reports the result of the dynamic panel oLs regressions for the entire sample of countries and the time period for which data are available. 11 Japan and Switzerland are not included since they had no political change in the sample. The dependent variable $y$ is the rate of GNP growth defined as: $y=\left[\frac{x_{t}-x_{t-4}}{x_{t-4}} \cdot 100\right]$; where $x_{t}-$ level of real GNP 
Table 1

Rational Partisan Theory

Dependent Variable: Rate of Growth of Output (Y)

\begin{tabular}{|c|c|c|}
\hline $\begin{array}{l}\text { Independent } \\
\text { Variables }\end{array}$ & $\begin{array}{c}(1) \\
\text { Coefficient } \\
\text { (t-statistics) }\end{array}$ & $\begin{array}{c}(2) \\
\text { Coefficient } \\
\text { (t-statistics) }\end{array}$ \\
\hline Constant & $\begin{array}{c}0.13 \\
(0.52)\end{array}$ & $\begin{array}{c}-0.17 \\
(-0.78)\end{array}$ \\
\hline$Y(-1)$ & $\begin{array}{c}0.713 \\
(28.2)\end{array}$ & $\begin{array}{r}0.610 \\
(17.28)\end{array}$ \\
\hline$Y(-2)$ & $\begin{array}{c}-0.062 \\
(-2.55)\end{array}$ & $\begin{array}{l}-0.01 \\
(-0.27)\end{array}$ \\
\hline YW & $\begin{array}{r}0.353 \\
(11.80)\end{array}$ & $\begin{array}{r}0.303 \\
(9.30)\end{array}$ \\
\hline $\operatorname{DRPT} 6(-1)$ & $\begin{array}{c}-0.40 \\
(-3.37)\end{array}$ & $\begin{array}{l}-0.62 \\
(-4.51)\end{array}$ \\
\hline USA & $\begin{array}{l}-0.45 \\
(-1.48)\end{array}$ & $\begin{array}{c}0.21 \\
(0.82)\end{array}$ \\
\hline UK & $\begin{array}{c}-0.63 \\
(-2.06)\end{array}$ & $\begin{array}{c}-0.02 \\
(-0.06)\end{array}$ \\
\hline Germany & $\begin{array}{l}-0.36 \\
(-1.18)\end{array}$ & $\begin{array}{c}0.29 \\
(1.10)\end{array}$ \\
\hline France & $\begin{array}{c}-0.14 \\
(-0.44)\end{array}$ & $\begin{array}{c}0.50 \\
(1.82)\end{array}$ \\
\hline Canada & $\begin{array}{c}0.13 \\
(0.45)\end{array}$ & $\begin{array}{c}0.83 \\
(3.14)\end{array}$ \\
\hline Italy & $\begin{array}{c}0.05 \\
(0.17)\end{array}$ & \\
\hline Sweden & $\begin{array}{l}-0.55 \\
(-1.62)\end{array}$ & \\
\hline Belgium & $\begin{array}{c}-0.42 \\
(-1.38)\end{array}$ & \\
\hline Austria & $\begin{array}{c}0.15 \\
(0.49)\end{array}$ & \\
\hline
\end{tabular}


Table 1 (continued)

Rational Partisan Theory

Dependent Variable: Rate of Growth of Output (Y)

\begin{tabular}{lcc}
\hline $\begin{array}{c}\text { Independent } \\
\text { Variables }\end{array}$ & $\begin{array}{c}(1) \\
\text { Coefficient } \\
\text { (t-statistics) }\end{array}$ & $\begin{array}{c}(2) \\
\text { Coefficient } \\
\text { (t-statistics) }\end{array}$ \\
\hline Norway & -0.02 & \\
Finland & $(-0.09)$ & \\
Ireland & 0.05 & \\
Australia & $(0.16)$ & \\
& 0.46 & 0.71 \\
New Zealand & $(1.14)$ & $(2.67)$ \\
& 0.03 & 0.13 \\
Denmark & $(0.11)$ & $(0.49)$ \\
$R^{2}$ & -0.48 & \\
& $(-1.57)$ & 0.60 \\
\hline
\end{tabular}


in quarter $t$. The regressors are self explanatory: $\mathrm{yw}_{t}$ is the world growth average (described above); the $A R(2)$ specification has been chosen as the "best" using standard techniques; the remaining regressors are country dumnies.

The political dummy DRPT6 has the correct sign and is statistically significant at the 1 percent confidence level: a change in government to the right (left) leads to a transitory fall (increase) in output growth. The one quarter lag in the political dumm is consistent with a reasonable interval between change of regime (in quarter $t$ ) and change of policy (in period $t+1$ ). The regressions with DRPT 4 and DRPT 8 (available upon request) yield analogous results: the pattern of the coefficients suggests that partisan effects are observable from about the second to the eighth/ninth quarters after the election. These results are consistent with findings on United States data by Alesina and Sachs (1988) and Alesina (1988a). 12

In column 2 of the same table we present the result of the same regression for a subset of countries which have either a "pure" two-party system or at least more clearly identifiable "left" and "right" coalitions. These are US, UK, France, Germany, Australia, New Zealand, Sweden, and Canada. The other countries in the sample have more fragmented political systems with governments formed with large coalitions of parties (often center-left) which sometimes are short lived and unstable. For obvious reasons, the second group of countries is less likely to exhibit regular partisan cycles. In the second regression, in fact, the coefficients on the political dummy are much larger in absolute value and even more precisely estimated. 
The values of the coefficients in the second column of Table 1 imply that about eighteen months after a change of regime toward the right (left) the rate of growth of GNP is about 1.3 percent below (above) "normal". Thus, the difference in the rate of growth between the beginning of a left wing government and the beginning of a right wing government reaches a peak of about 2.6 percent.

In Table 2 the dependent variable is the difference ( $U_{t}^{D I F}$ ) between the domestic unemployment rate, $\left(U_{t}\right)$ and the "OECD unemployment rate," $U_{t}$, defined analogously to the average GNP growth. In evaluating results on employment one has to be cautious because of problems of hysteresis (see Blanchard and Summers, 1986). By taking the difference of domestic unemployment from a world weighted average, unit roots problems are somewhat mitigated, but certainly not eliminated. Table 2 shows results which are quite consistent with those on GNP growth. The political dumny is significant at the 1 percent level and the fit improves when the sample is restricted to seven bi-partisan countries (note that New Zealand is missing from these regressions because of lack of quarterly unemployment data). The dummy DRPT6 is lagged two quarters to capture the slow response of unemployment to policy changes relative to output. In any case, analogous results (avallable upon request) are obtained if this variable is lagged only one quarter or when DRPT4 and DRPT8 are used. The values of the coefflclents in the second column of Table 2 imply that about six quarters after a change of regime toward the right (left) the unemployment rate is about 1.5 percentage points above (below) normal. 13 
Table 2

Test of Rational Partisan Theory

Dependent Variable: $U^{\text {DIF }}$

\begin{tabular}{|c|c|c|}
\hline Variable & $\begin{array}{c}(1) \\
\text { Coefficient } \\
\text { (t-statistic) }\end{array}$ & $\begin{array}{c}(2) \\
\text { Coefficient } \\
\text { (t-statistic) }\end{array}$ \\
\hline Constant & $\begin{array}{r}0.153 \\
(3.38)\end{array}$ & $\begin{array}{r}0.101 \\
(2.96)\end{array}$ \\
\hline$U^{D I F}(-1)$ & $\begin{array}{r}1.286 \\
(48.41)\end{array}$ & $\begin{array}{r}1.334 \\
(39.50)\end{array}$ \\
\hline $\mathrm{U}^{\mathrm{DIF}}(-2)$ & $\begin{array}{r}-0.301 \\
(-11.25)\end{array}$ & $\begin{array}{r}-0.361 \\
(-10.58)\end{array}$ \\
\hline $\operatorname{DRPT} 6(-2)$ & $\begin{array}{r}0.057 \\
(2.85)\end{array}$ & $\begin{array}{r}0.083 \\
(3.10)\end{array}$ \\
\hline Australia & $\begin{array}{r}-0.127 \\
(-2.15)\end{array}$ & $\begin{array}{r}-0.082 \\
(-1.67)\end{array}$ \\
\hline Austria & $\begin{array}{c}-0.218 \\
(-3.32)\end{array}$ & \\
\hline Belgium & $\begin{array}{c}-0.031 \\
(-0.57)\end{array}$ & \\
\hline Canada & $\begin{array}{r}-0.130 \\
(-2.35)\end{array}$ & $\begin{array}{r}-0.053 \\
(-1.23)\end{array}$ \\
\hline Denmark & $\begin{array}{r}-0.094 \\
(-1.52)\end{array}$ & \\
\hline Finland & $\begin{array}{r}-0.164 \\
(-2.81)\end{array}$ & \\
\hline France & $\begin{array}{r}-0.110 \\
(-1.83)\end{array}$ & $\begin{array}{c}-0.06 \\
(-1.25)\end{array}$ \\
\hline Germany & $\begin{array}{r}-0.140 \\
(-2.31)\end{array}$ & $\begin{array}{r}-0.116 \\
(-2.16)\end{array}$ \\
\hline Ireland & $\begin{array}{c}0.071 \\
(1.03)\end{array}$ & \\
\hline Italy & $\begin{array}{r}-0.074 \\
(-1.32)\end{array}$ & \\
\hline
\end{tabular}


Table 2 (continued)

Test of Rational Partisan Theory

Dependent Variable: UDIF

\begin{tabular}{lcc}
\hline Variable & $\begin{array}{c}(1) \\
\text { Coefficient } \\
\text { (t-statistic) }\end{array}$ & $\begin{array}{c}(2) \\
\text { Coefficient } \\
(t-\text {-statistic) }\end{array}$ \\
\hline Norway & -0.218 & \\
Sweden & $(-3.15)$ & -0.198 \\
UK & -0.208 & $(-3.32)$ \\
USA & $(-3.32)$ & -0.082 \\
R & -0.133 & $(-1.80)$ \\
$\mathrm{R}^{2}$ & -0.139 & -0.059 \\
& $(-2.49)$ & $(-1.37)$ \\
\hline
\end{tabular}


Let us now turn to inflation. The theory implies that one should observe permanent differences across governments on the inflation rate. Thus, we have defined a political dummy, RADM, as follows:

$$
\operatorname{RADM}= \begin{cases}+1 & \begin{array}{l}
\text { if a right wing government is in office, includ- } \\
\text { ing the quarter of the change of government }
\end{array} \\
-1 & \begin{array}{l}
\text { if a left wing government is in office includ- } \\
\text { ing the quarter of the change of government. }
\end{array}\end{cases}
$$

In Table 3 the dependent variable is domestic inflation $(\pi)$ defined as the rate of change of $\mathrm{CPI}: \pi_{t}=\left[\frac{\mathrm{CPI} I_{t}-\mathrm{CPI} I_{t-4}}{\mathrm{CPI} I_{t-4}} \cdot 100\right]$. The variable for world inflation $(\pi W)$ is defined analogously to the world output growth. 14

In the first regression, which includes the entire sample of countries, the sign of the coefficient on RADM(-1) is correct and it is marginally insignificant at the 10 percent level ( $t-1.55)$. The second regression includes only the eight "bi-partisan" countries: here the coefficient on $\operatorname{RADM}(-1)$ is larger and significant at the 5 percent level.

The value of the coefficients in the second regressions imply a difference in the steady state inflation rate between the two regimes of about 1.4 percent. This relatively low value reflects the fact that our sample includes the sixties, with a low and stable inflation and countries, such as Germany, with a low inflation rate throughout the sample period. We have run the same regressions of Table 3 for the post-fixed exchange rates regimes, from 1972.1 to 1987.4 . In these regressions (available upon request) the coefficient on the RADM dummy is more precisely estimated and implies (in the sample of 8 "bi-partisan" countries) a difference in the inflation rate across political regimes of about 2.5 percent. 
Table 3

Rational Partisan Theory

Dependent Variable: $\pi$

\begin{tabular}{|c|c|c|}
\hline Variable & $\begin{array}{c}(1) \\
\text { Coefficient } \\
\text { (t-statistic) }\end{array}$ & $\begin{array}{c}(2) \\
\text { Coefficient } \\
\text { (t-statistic) }\end{array}$ \\
\hline Constant & $\begin{array}{r}-0.082 \\
(-0.69)\end{array}$ & $\begin{array}{r}0.589 \\
(4.78)\end{array}$ \\
\hline$\pi(-1)$ & $\begin{array}{r}1.085 \\
(45.55)\end{array}$ & $\begin{array}{r}1.210 \\
(35.26)\end{array}$ \\
\hline$\pi(-2)$ & $\begin{array}{r}-0.137 \\
(-3.92)\end{array}$ & $\begin{array}{r}-0.272 \\
(-5.16)\end{array}$ \\
\hline$\pi(-3)$ & $\begin{array}{r}-0.097 \\
(-4.34)\end{array}$ & $\begin{array}{c}-0.075 \\
(-2.31)\end{array}$ \\
\hline$\pi \mathrm{W}$ & $\begin{array}{r}0.146 \\
(13.20)\end{array}$ & $\begin{array}{r}0.127 \\
(9.38)\end{array}$ \\
\hline $\operatorname{RADM}(-1)$ & $\begin{array}{c}-0.05 \\
(-1.55)\end{array}$ & $\begin{array}{r}-0.082 \\
(-2.13)\end{array}$ \\
\hline Australia & $\begin{array}{r}0.332 \\
(2.18)\end{array}$ & $\begin{array}{r}-0.306 \\
(-2.27)\end{array}$ \\
\hline Austria & $\begin{array}{c}-0.062 \\
(-0.40)\end{array}$ & \\
\hline Belgium & $\begin{array}{c}0.031 \\
(0.20)\end{array}$ & \\
\hline Canada & $\begin{array}{c}0.08 \\
(0.52)\end{array}$ & $\begin{array}{r}-0.574 \\
(-3.94)\end{array}$ \\
\hline Denmark & $\begin{array}{r}0.358 \\
(2.31)\end{array}$ & \\
\hline Finland & $\begin{array}{c}0.41 \\
(2.69)\end{array}$ & \\
\hline France & $\begin{array}{c}0.336 \\
(2.19)\end{array}$ & $\begin{array}{r}-0.294 \\
(-2.19)\end{array}$ \\
\hline Germany & $\begin{array}{r}-0.251 \\
(-1.64)\end{array}$ & $\begin{array}{r}-0.853 \\
(-5.68)\end{array}$ \\
\hline
\end{tabular}


Table 3 (continued)

Rational Partisan Theory

Dependent Variable: $\pi$

\begin{tabular}{lcc} 
Variable & $\begin{array}{c}(1) \\
\text { Coefficient } \\
\text { (t-statistic) }\end{array}$ & $\begin{array}{c}(2) \\
\text { Coefficient } \\
\text { (t-statistic) }\end{array}$ \\
\hline Ireland & 0.66 & \\
Italy & $(4.25)$ & \\
New Zealand & $(4.19)$ & \\
Norway & 0.67 & \\
Sweden & 0.304 & $-29)$ \\
& $(1.98)$ & -0.403 \\
UK & 0.270 & $(-2.82)$ \\
& $(1.74)$ & -0.14 \\
USA & 0.522 & $(-1.04)$ \\
& $(3.38)$ & -0.65 \\
$\mathrm{R}^{2}$ & -0.037 & $(-4.55)$ \\
& $(-0.24)$ & 0.95 \\
& 0.94 & \\
\hline
\end{tabular}


In fact, we have tested whether all the regressions of Tables 1,2 and 3 improve in the post 1971 period, since in the fixed exchange rate period (1960-71 in our sample) the macroeconomic policies of each countries were more constrained and integrated. All the t-statistics on the political dummies improve and the value of the coefficients increase in absolute value in the post 1971 regressions, which are available. However, the problem in pursuing this comparison, pre and post-1971, is that there are very few changes of regimes in this period (see Table A-1); in many countries there are no changes of regimes in the sixties. Thus, the political dummies pre-1971 regression would be very imprecisely estimated and hard to compare with the post-1971 sample.

In summary, these results are favorable to the RPT. The implication of this hypothesis is not rejected on both the level of economic activity (growth and unemployment) and inflation, particularly for a sub-set of countries with more clearly identifiable government changes from left to right and vice versa. 15

\section{4 "Partisan Theory" with Permanent Effects \\ Hibbs' PT 1mplies permanent differences in output and unemployment in} addition to permanent differences in inflation across governments. Thus, one way of comparing the Hibbs' PT with the RPT is to run the same regresslons of Tables 1 and 2 using the "permanent" partisan dummy RADM rather than the "transitory" political dummy DRPTN. The results are shown in Tables 4 and 5 : all the coefficients on the political dummy are Insignificant, even though with the right sign. In these tables the fixed effects coefficients are not reported since they are very similar to those of Tables 1 and 2 . Additional 
Table 4

Partisan Theory (Hibbs)

Dependent Variable: $Y$

\begin{tabular}{lcc}
\hline Variable * & $\begin{array}{c}(1) \\
\text { Coefficient } \\
\text { (t-statistic) }\end{array}$ & $\begin{array}{c}(2) \\
\text { Coefficient } \\
\text { (t-statistic) }\end{array}$ \\
\hline Constant & 0.13 & -0.18 \\
Y (-1) & $(0.52)$ & $(-0.80)$ \\
& 0.720 & 0.629 \\
Y(-2) & $(28.47)$ & $(17.76)$ \\
& -0.061 & -0.01 \\
YW & $(-2.53)$ & $(-0.27)$ \\
& 0.349 & 0.289 \\
RADM(-1) & $(11.63)$ & $(8.78)$ \\
& -0.04 & -0.03 \\
$R^{2}$ & $(-0.71)$ & $(-0.47)$ \\
& 0.61 & 0.59
\end{tabular}

* The estimated regression includes country fixed effects that are not reported in the table 
Table 5

Partisan Theory (Hibbs)

Dependent Variable : $\mathrm{U}^{\text {DIr }}$

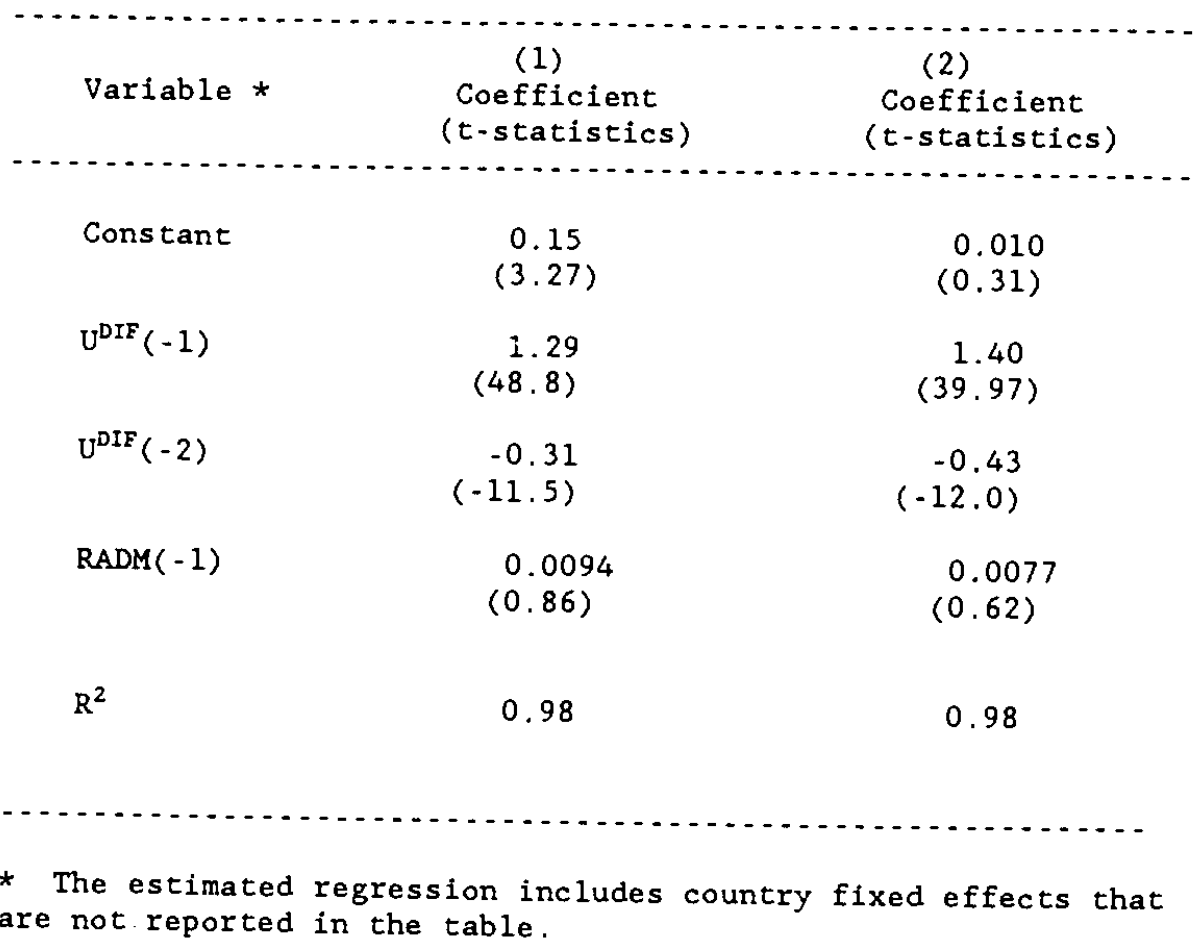


regressions with alternative lag structures (for instance lagging RADM more than one quarter) yield no support for the theory.

The results of section 3.2 and 3.3 viewed together, indirectly provide some empirical support to the inflation bias model of Kydland and Prescott (1977) and Barro and Gordon $(1983 a, b)$. In fact, these regressions show that a permanent difference in inflation rate is associated with temporary deviations of output and unemployment from trend. Thus, the governments that are more concerned about growth and unemployment relative to inflation, after a temporary initial expansion, are caught in the sub-optimal equilibrium with an inflation bias. In fact, inflation remains high even though the level of economic activity returns to its "natural" value. This is precisely the feature of the sub-optimal time consistent equilibrium.

\subsection{The "Political Business Cycle"}

Nordhaus' (1975) PBC model can be tested on growth and unemployment by constructing a political dumy of the following form:

$$
N R D N= \begin{cases}1 & \begin{array}{l}
\text { in the }(N-1) \text { quarters preceding an election } \\
\text { and in the election quarter }
\end{array} \\
0 & \text { otherwise }\end{cases}
$$

We have chosen $N-4,6$ and 8 . A relatively short pre-electoral output expansion is consistent with this theory based upon a short sighted electorate, Nordhaus (1975, 1989). Furthermore, since in many countries in the sample several elections occur in less than four year intervals, a longer specification of the preelectoral period would seem unreasonable. 
Tables 6 and 7 report the results on output and unemployment for the 18 countries in the sample, using NRD6. (The fixed effect coefficients are not reported.) In both tables the coefficients are insignificant; in the growth regression the coefficient has the opposite sign from the theory prediction. Several alternative specifications with NRD4 and NRD8, using the difference of domestic growth from the world as the dependent variable and alternative lag structures, yield no support for the theory. ${ }^{16}$ In fact, the coefficient on the political dumny has the "wrong" sign in the majority of the regressions.

We also tested whether the NRD dummy approaches statistical significance, when partisan effects are held constant. Regressions including both the DRPT and the NRD dummies were run. Once again no support for the PBC was found, while the DRPT dummy remained statistically significant (results are ava1lable). 17

The PBC not only as formulated in Nordhaus (1975) but also, with caveats discussed above, in the "rational" models by Rogoff and Sibert (1988) and Persson and Tabellini (1990) implies an increase of the inflation rate around elections. In particular, the model by Rogoff and sibert (1988) implies that pre-electoral manipulation of monetary and fiscal policy, used to signal the government competence in providing public goods and services without raising taxes implies an increase of inflation immediately after each election.

Furthermore, governments may prefer to raise prices under their direct control after, rather than before elections, thus directly contributing to a post electoral upward jump in inflation. We have tested this implication in Table 8, where the dummy ELE is defined as follows:

$$
E L E= \begin{cases}1 & \begin{array}{l}
\text { in the } 4 \text { quarters following an election, and in } \\
\text { the election quarter. }
\end{array} \\
0 & \text { otherwise }\end{cases}
$$


Table 6

Test For Political Business Cycle Theory

Dependent Variable: $Y$

\begin{tabular}{lcc}
\hline Variable* & $\begin{array}{c}(1) \\
\text { Coefficient } \\
(\text { t-statistic) }\end{array}$ & $\begin{array}{c}(2) \\
\text { Coefficient } \\
\text { (t-statistic) }\end{array}$ \\
\hline Constant & 0.13 & -0.19 \\
Y(-1) & $0.52)$ & $(-0.81)$ \\
& 0.732 & 0.631 \\
Y(-2) & $(29.49)$ & $(17.27)$ \\
YW & -0.059 & -0.015 \\
& $(-2.48)$ & $(-0.43)$ \\
NRD6 & 0.344 & 0.280 \\
& $(12.03)$ & $(8.47)$ \\
$R^{2}$ & -0.11 & 0.06 \\
& $(-0.97)$ & $(0.49)$ \\
\end{tabular}

* The estimated regression includes country fixed effects that are not reported in the table.

Table 7

Political Business Cycle Theory

Dependent Variable: $U^{\text {DIF }}$

\begin{tabular}{lcc}
\hline Variable * & $\begin{array}{c}(1) \\
\text { Coefficient } \\
\text { (t-statistic) }\end{array}$ & $\begin{array}{c}(2) \\
\text { Coefficient } \\
\text { (t-statistic) }\end{array}$ \\
\hline Constant & 0.167 & 0.020 \\
UDF $(-1)$ & $1.77)$ & $(0.68)$ \\
& $(50.98)$ & 1.433 \\
$\mathrm{U}^{\text {DIF }}(-2)$ & -0.335 & $(39.67)$ \\
NRD6 & $(-12.79)$ & -0.446 \\
& -0.014 & $(-12.08)$ \\
$\mathrm{R}^{2}$ & $(-0.80)$ & -0.001 \\
& 0.99 & $(-0.63)$ \\
\end{tabular}

* The estimated regression includes country fixed effects that are not reported in the table. 
Table 8

Political Business Cycle

Dependent Variable: $\pi$

\begin{tabular}{lc}
\hline Variable * & $\begin{array}{c}\text { Coefficient } \\
(\text { t-statistic })\end{array}$ \\
\hline Constant & -0.129 \\
$(-1.06)$ & 1.078 \\
$\pi(-2)$ & $(46.93)$ \\
$\pi(-3)$ & -0.114 \\
$\pi W$ & $(-3.40)$ \\
& -0.111 \\
ELE & $(-5.17)$ \\
& 0.141 \\
$R^{2}$ & $(13.12)$ \\
& 0.263 \\
& $(4.67)$ \\
& 0.93 \\
\hline
\end{tabular}

* The estimated regression includes country fixed effects that are not reported in the table. 
The dumny ELE is significant at the one per cent level. Additional regressions (available upon request) confirm that the upward jump in inflation does not occur before the election, but only in the election quarter and lasts three to five quarters. If confirmed by direct findings on policy instruments, this result suggests that around elections monetary and fiscal policy instruments may be manipulated, even though these policies do not seem to affect real economic activity, as implied by Rogoff and Sibert (1988) and Rogoff (1990). Alesina (1989) presents some qualitative evidence which suggests the possibility that budget deficits increase in election years.

\section{Country Results}

In this section we analyze country by country results, starting with the RPT. Table 9 reports the results on GNP growth. For each country in the sample we report the regression with the best fit chosen between the six dummies DRPTN $(-J)$ with $N-4,6,8$ and $J-1,2$. Countries may differ with regard to the time delay in implementing a new policy after a regime change or with regard to how persistent the transitory increase in output will be after the policy change. This is the reason why the best fit for DRPTN might occur at different lags for different countries. For economy of space, we report the results on unemployment in Appendix (Table A-3) without comments. The results of Table 9 are very consistent with those on unemployment: the rare differences will be pointed out. Table 10 displays the results on inflation. We report the "best fit" within five regressions with $\operatorname{RADM}(-J) \mathrm{J}-1, \ldots 5$. Longer lags in the inflation regression, relative to the growth regression, can be easily explained by the lag between output and inflation movements 
Table 9

Rational Partisan Theory

Dependent Variable: $Y$

(t-statistics in parentheses)

\begin{tabular}{|c|c|c|c|c|c|c|c|c|}
\hline Country & Constant & $Y(-1)$ & $Y(-2)$ & $Y W$ & $\operatorname{DRPT} 6(-1)$ & $\operatorname{DRPTN}(-\mathrm{J}) \star \star \star$ & $\mathrm{R}^{2}$ & D. W \\
\hline Australia & $\begin{array}{r}0.236 \\
(0.58)\end{array}$ & $\begin{array}{r}0.595 \\
(8.41)\end{array}$ & & $\begin{array}{r}0.374 \\
(3.82)\end{array}$ & & $\begin{array}{l}-0.427 \quad(8,2) \\
(-1.09)\end{array}$ & 0.56 & 2.03 \\
\hline Austria & $\begin{array}{c}-0.437 \\
(-0.550)\end{array}$ & $\begin{array}{c}0.848 \\
(8.954)\end{array}$ & $\begin{array}{l}-0.169 \\
(-1.822)\end{array}$ & $\begin{array}{c}0.544 \\
(2.738)\end{array}$ & $\begin{array}{l}-1.207 \\
(-1.389)\end{array}$ & & 0.634 & 2.06 \\
\hline Belgium* & $\begin{array}{l}-1.520 \\
(-2.602)\end{array}$ & $\begin{array}{c}0.580 \\
(6.328)\end{array}$ & $\begin{array}{c}0.147 \\
(1.381)\end{array}$ & $\begin{array}{c}0.831 \\
(5.309)\end{array}$ & & $\begin{array}{l}-0.027(8,2) \\
(-0.061)\end{array}$ & 0.697 & 2.15 \\
\hline Canada & $\begin{array}{c}0.387 \\
(1.237)\end{array}$ & $\begin{array}{c}0.709 \\
(7.621)\end{array}$ & $\begin{array}{l}-0.234 \\
(-2.822)\end{array}$ & $\begin{array}{c}0.533 \\
(5.592)\end{array}$ & & $\begin{array}{l}-0.469(4,2) \\
(-1.220)\end{array}$ & 0.716 & 1.95 \\
\hline Denmark & $\begin{array}{l}-0.008 \\
(-0.02)\end{array}$ & $\begin{array}{r}0.776 \\
(8.25)\end{array}$ & $\begin{array}{l}-0.124 \\
(1.35)\end{array}$ & $\begin{array}{r}0.298 \\
(3.61)\end{array}$ & & $\begin{array}{r}-0.467 \quad(4,1) \\
(-1.37)\end{array}$ & 0.67 & 2.02 \\
\hline Finland & $\begin{array}{r}1.035 \\
(1.56)\end{array}$ & $\begin{array}{r}0.362 \\
(2.91)\end{array}$ & $\begin{array}{r}0.184 \\
(1.49)\end{array}$ & $\begin{array}{r}0.199 \\
(1.38)\end{array}$ & & $\begin{array}{l}-0.852(8.2) \\
(-1.65)\end{array}$ & 0.31 & 2.08 \\
\hline France* & $\begin{array}{c}0.016 \\
(0.033)\end{array}$ & $\begin{array}{c}0.282 \\
(2.566)\end{array}$ & $\begin{array}{c}0.200 \\
(1.807)\end{array}$ & $\begin{array}{c}0.334 \\
(3.103)\end{array}$ & & $\begin{array}{l}-0.802(4.1) \\
(-1.390)\end{array}$ & 0.446 & 1.88 \\
\hline Germany & $\begin{array}{c}-0.406 \\
(-1.211)\end{array}$ & $\begin{array}{l}0.525 \\
(7.725)\end{array}$ & & $\begin{array}{c}0.492 \\
(5.228)\end{array}$ & & $\begin{array}{l}-0.699(8,2) \\
(-2.418)\end{array}$ & 0.656 & 2.01 \\
\hline Irel and & $\begin{array}{r}-0.649 \\
(-0.59)\end{array}$ & $\begin{array}{l}0.491 \\
(4.06)\end{array}$ & & $\begin{array}{l}1.137 \\
(3.00)\end{array}$ & $\begin{array}{r}-1.190 \\
(-1.44)\end{array}$ & & 0.62 & 1.82 \\
\hline Italy & $\begin{array}{r}0.251 \\
(0.40)\end{array}$ & $\begin{array}{l}0.942 \\
(9.82)\end{array}$ & $\begin{array}{l}-0.234 \\
(-2.45)\end{array}$ & $\begin{array}{r}0.275 \\
(2.09)\end{array}$ & & $\begin{array}{l}-0.205(4,1) \\
(-0.249)\end{array}$ & 0.65 & 2.10 \\
\hline
\end{tabular}


Table 9 (continued)

\begin{tabular}{|c|c|c|c|c|c|c|c|c|}
\hline Country & const & $Y(-1)$ & $Y(-2)$ & $\mathrm{YW}$ & $\operatorname{DRPT} 6(-1)$ & $\operatorname{DRPTN}(-\mathrm{J})$ & $\mathrm{R}^{2}$ & D.W. \\
\hline Netherlands & $\begin{array}{l}-1.683 \\
(-3.405)\end{array}$ & $\begin{array}{c}0.513 \\
(5.407)\end{array}$ & $\begin{array}{c}0.151 \\
(1.734)\end{array}$ & $\begin{array}{c}0.838 \\
(6.201)\end{array}$ & & $\begin{array}{l}0.076(4,1) \\
(0.156)\end{array}$ & 0.758 & 1.94 \\
\hline New Zealand & $\begin{array}{l}-0.077 \\
(-0.282)\end{array}$ & $\begin{array}{l}0.836 \\
(8.40)\end{array}$ & $\begin{array}{l}-0.059 \\
(-0.61)\end{array}$ & $\begin{array}{l}0.175 \\
\quad(2.77)\end{array}$ & & $\begin{array}{l}-0.542 \quad(8.1) \\
(-1.91)\end{array}$ & 0.76 & 1.93 \\
\hline Norway & $\begin{array}{r}0.819 \\
(2.66)\end{array}$ & $\begin{array}{r}0.859 \\
(8.88)\end{array}$ & $\begin{array}{l}-0.141 \\
(-1.45)\end{array}$ & $\begin{array}{l}-0.093 \\
(1.75)\end{array}$ & & $\begin{array}{l}-0.265 \quad(4.1) \\
(-1.21)\end{array}$ & 0.64 & 2.01 \\
\hline Sweden & $\begin{array}{r}0.667 \\
(1.55)\end{array}$ & $\begin{array}{l}0.461 \\
(4.48)\end{array}$ & & $\begin{array}{c}0.158 \\
(1.47)\end{array}$ & $\begin{array}{r}-1.226 \\
(-2.23)\end{array}$ & & 0.35 & 1.95 \\
\hline UK & $\begin{array}{c}0.214 \\
(0.569)\end{array}$ & $\begin{array}{c}0.502 \\
(6.121)\end{array}$ & & $\begin{array}{c}0.262 \\
(2.695)\end{array}$ & & $\begin{array}{l}-0.455(8,2) \\
(-1.365)\end{array}$ & 0.425 & 1.87 \\
\hline UK $(* * *)$ & $\begin{array}{l}-0.018 \\
(-0.043)\end{array}$ & $\begin{array}{c}0.533 \\
(4.513)\end{array}$ & $\begin{array}{l}-0.144 \\
(-1.294)\end{array}$ & $\begin{array}{c}0.455 \\
(3.541)\end{array}$ & & $\begin{array}{l}-0.902(8,2) \\
(-2.03)\end{array}$ & 0.520 & 1.96 \\
\hline USA & $\begin{array}{r}0.362 \\
(1.34)\end{array}$ & $\begin{array}{r}1.068 \\
(11.95)\end{array}$ & $\begin{array}{l}-0.375 \\
(-4.47)\end{array}$ & $\begin{array}{r}0.154 \\
(2.20)\end{array}$ & $\begin{array}{l}-0.894 \\
(-3.43)\end{array}$ & & 0.80 & 2.14 \\
\hline
\end{tabular}

(*) In the regressions for these countries a third lag of the dependent variable was significant, and was included. For France its coefficients were 0.183 ( 1.721 ); for Belgium $-0.241(-2.937)$.

(**) In the regressions where $\operatorname{DRPTN}(-\mathrm{J})$ is used the two figures in parenthesis after the coefficient estimate represent the horizon of the dumy variable $(N-4,6,8)$ and the lag in DRPTN chosen in the regression. For example $(8,2)$ in the Australian regression means that we used DRPT8 $(-2)$.

(***) Sample period: 1970:1-1987:4. 
Table 10

Partisan Theory

Dependent Variable: $\pi$

(t-statistics in parentheses)

\begin{tabular}{|c|c|c|c|c|c|c|c|c|}
\hline Country & Constant & $\pi \mathrm{W}$ & $\pi_{t-1}$ & $\pi_{t-2}$ & $\operatorname{RADM}(-1)$ & $\operatorname{RADM}(-\mathbf{i})$ & $\mathrm{R}^{2}$ & D.W. \\
\hline Australia & $\begin{array}{c}0.365 \\
(1.679)\end{array}$ & $\begin{array}{c}0.151 \\
(3.500)\end{array}$ & $\begin{array}{c}1.114 \\
(11.954)\end{array}$ & $\begin{array}{l}-0.267 \\
(-3.075)\end{array}$ & $\begin{array}{c}-0.291 \\
(-2.396)\end{array}$ & & 0.948 & 2.039 \\
\hline Austria (E) & $\begin{array}{c}0.472 \\
(1.922)\end{array}$ & $\begin{array}{c}0.132 \\
(3.209)\end{array}$ & $\begin{array}{c}0.848 \\
(8.817)\end{array}$ & $\begin{array}{l}-0.112 \\
(-1.201)\end{array}$ & $\begin{array}{c}0.010 \\
(-0.064)\end{array}$ & & 0.835 & 1.939 \\
\hline Belgium (a) & $\begin{array}{c}0.004 \\
(0.024)\end{array}$ & $\begin{array}{c}0.141 \\
(3.908)\end{array}$ & $\begin{array}{c}1.153 \\
(12.416)\end{array}$ & $\begin{array}{c}-0.309 \\
(-3.646)\end{array}$ & & $\begin{array}{c}0.243 \\
(0.289)\end{array}$ & 0.952 & 1.967 \\
\hline Canada (c) & $\begin{array}{c}0.035 \\
(0.325)\end{array}$ & $\begin{array}{c}0.132 \\
(4.482)\end{array}$ & $\begin{array}{c}1.162 \\
(12.648)\end{array}$ & $\begin{array}{c}-0.300 \\
(-3.583)\end{array}$ & & $\begin{array}{c}-0.014 \\
(-0.212)\end{array}$ & 0.973 & 2.065 \\
\hline Dennark (b) & $\begin{array}{c}1.066 \\
(3.205)\end{array}$ & $\begin{array}{c}0.302 \\
(4.339)\end{array}$ & $\begin{array}{c}0.816 \\
(8.622)\end{array}$ & $\begin{array}{l}-0.210 \\
(-2.392)\end{array}$ & & $\begin{array}{c}-0.457 \\
(-2.920)\end{array}$ & 0.828 & 2.032 \\
\hline Finland (a) & $\begin{array}{c}0.285 \\
(1.279)\end{array}$ & $\begin{array}{c}0.173 \\
(3.560)\end{array}$ & $\begin{array}{c}1.205 \\
(13.416)\end{array}$ & $\begin{array}{c}-0.373 \\
(-4.400)\end{array}$ & & $\begin{array}{c}0.119 \\
(-0.940)\end{array}$ & 0.938 & 2.049 \\
\hline France & $\begin{array}{c}0.540 \\
(2.868)\end{array}$ & $\begin{array}{c}0.272 \\
(5.997)\end{array}$ & $\begin{array}{c}1.066 \\
(11.634)\end{array}$ & $\begin{array}{l}-0.330 \\
(-4.231)\end{array}$ & $\begin{array}{l}-0.308 \\
(-2.630)\end{array}$ & & 0.970 & 1.677 \\
\hline Germany $(d, a)$ & $\begin{array}{c}0.309 \\
(2.136)\end{array}$ & $\begin{array}{c}0.029 \\
(1.316)\end{array}$ & $\begin{array}{c}1.100 \\
(11.615)\end{array}$ & $\begin{array}{l}-0.234 \\
(-2.543)\end{array}$ & & $\begin{array}{c}-0.164 \\
(-1.881)\end{array}$ & 0.928 & 1.987 \\
\hline Ireland & $\begin{array}{l}-0.101 \\
(-0.308)\end{array}$ & $\begin{array}{c}0.544 \\
(6.576)\end{array}$ & $\begin{array}{c}0.674 \\
(7.177)\end{array}$ & $\begin{array}{c}0.012 \\
(0.147)\end{array}$ & $\begin{array}{c}-0.135 \\
(-0.777)\end{array}$ & & 0.932 & 2.011 \\
\hline Italy & $\begin{array}{l}-0.179 \\
(-0.727)\end{array}$ & $\begin{array}{c}0.226 \\
(4.007)\end{array}$ & $\begin{array}{l}1.265 \\
(14.461)\end{array}$ & $\begin{array}{c}-0.386 \\
(-4.858)\end{array}$ & $\begin{array}{l}-0.156 \\
(-0.982)\end{array}$ & & 0.967 & 1.951 \\
\hline Ne therlands & $\begin{array}{c}0.121 \\
(0.361)\end{array}$ & $\begin{array}{c}0.111 \\
(2.616)\end{array}$ & $\begin{array}{c}0.835 \\
(8.590)\end{array}$ & $\begin{array}{c}0.009 \\
(0.096)\end{array}$ & $\begin{array}{l}-0.003 \\
(-0.017)\end{array}$ & & 0.851 & 1.964 \\
\hline
\end{tabular}


Table 10 (continued)

\begin{tabular}{|c|c|c|c|c|c|c|c|c|}
\hline Country & Constant & $\pi \mathrm{W}$ & $\pi_{t-1}$ & $\pi_{t-2}$ & $\operatorname{RADM}(-1)$ & $\operatorname{RADM}(-i)$ & $\mathrm{R}^{2}$ & D.W. \\
\hline New Zealand (d) & $\begin{array}{c}0.615 \\
(1.846)\end{array}$ & $\begin{array}{c}0.137 \\
(2.908)\end{array}$ & $\begin{array}{c}1.368 \\
(14.736)\end{array}$ & $\begin{array}{c}-0.504 \\
(-5.649)\end{array}$ & & $\begin{array}{c}-0.263 \\
(-1.478)\end{array}$ & 0.940 & 1.794 \\
\hline Norway & $\begin{array}{c}0.487 \\
(1.957)\end{array}$ & $\begin{array}{c}0.136 \\
(3.391)\end{array}$ & $\begin{array}{c}1.076 \\
(11.724)\end{array}$ & $\begin{array}{c}-0.255 \\
(-2.906)\end{array}$ & $\begin{array}{c}-0.037 \\
(-0.324)\end{array}$ & & 0.889 & 2.125 \\
\hline Sweden (a) & $\begin{array}{c}0.537 \\
(1.489)\end{array}$ & $\begin{array}{c}0.206 \\
(4.677)\end{array}$ & $\begin{array}{c}0.823 \\
(8.750)\end{array}$ & $\begin{array}{c}-0.064 \\
(-0.727)\end{array}$ & & $\begin{array}{c}0.082 \\
(0.507)\end{array}$ & 0.887 & 1.994 \\
\hline UK (d) & $\begin{array}{l}-0.022 \\
(-0.094)\end{array}$ & $\begin{array}{c}0.342 \\
(5.483)\end{array}$ & $\begin{array}{c}1.241 \\
(15.072)\end{array}$ & $\begin{array}{c}-0.461 \\
(-6.223)\end{array}$ & & $\begin{array}{c}-0.173 \\
(-1.395)\end{array}$ & 0.958 & 2.057 \\
\hline UK (d, g) & $\begin{array}{c}0.487 \\
(1.094)\end{array}$ & $\begin{array}{c}0.349 \\
(4.581)\end{array}$ & $\begin{array}{c}1.252 \\
(12.559)\end{array}$ & $\begin{array}{c}-0.505 \\
(-5.572)\end{array}$ & & $\begin{array}{c}-0.483 \\
(-2.397)\end{array}$ & 0.948 & 2.126 \\
\hline USA（c） & $\begin{array}{c}0.112 \\
(0.927)\end{array}$ & $\begin{array}{c}0.058 \\
(1.933)\end{array}$ & $\begin{array}{c}1.373 \\
(15.539)\end{array}$ & $\begin{array}{c}-0.460 \\
(-5.533)\end{array}$ & & $\begin{array}{c}-0.108 \\
(-1.660)\end{array}$ & 0.965 & 2.120 \\
\hline
\end{tabular}

(a) $\operatorname{RADM}(-5)$

(b) $\operatorname{RADM}(-4)$

(c) $\operatorname{RADM}(-3)$

(d) $\operatorname{RADM}(-2)$

(e) Germany had a large coalition of right and left parties between $66: 4$ and $69: 1$; also, following Alt (1985), the entrance of the FDP in the Social Democratic government in $72: 3$ is considered a movement to the right. To consider the movement from the right to centerleft in the 66-69 period and from left to center in the 72.82 period, the variable RADM assumes the value of -0.5 (instead of -1.0) in the first period and the value of -0.5 (instead of -1.0 ) in the second period. This finer variable (ADM) is lagged five quarters i.e. $(-5)$.

(f) For analogous reasoning to those ascribed to Germany, we used the ADM variable for Austria.

(g) Sample period: 1970:1-1987:4 
following changes in macroeconomic policies. The results can be summarized in three points:

1) In a large group of countries which includes Australia, Denmark, Germany, France, New Zealand, the US, and the UK, all the regressions on growth, inflation and also unemployment (see Table A-3) show clear evidence of RPT, although not all the coefficients on the political variables are significant at the usual confidence levels ( 5 or 10 percent) in every regression. Note that Table A-3 shows that the regressions on unemployment for Australia, Denmark, France, Germany and the U.S. show a five percent level of significance on the coefficient on the political dumny (Table A-3). The results on the UK are greatly strengthened if the sample is restricted to the post-fixed rates period. The regressions on the sample 1970-1987 in Tables 9 and 10 show significant coefficients on the political dummy at the 5 percent level. The significant difference between the pre- and post-1971 results for the UK is explained primarily by the observation of the labor government elected in october 1964. This government, constrained by a commitment not to devalue the pound, could not pursue expansionary policies. Thus, UK growth in this period (1964-66) does not outperform the relatively rapid OECD average growth.

2) In a second group of countries which includes Austria, Belgium, Finland, Ireland, the Netherlands, Norway, Sweden, the coefficients on the political dummies exhibit the sign predicted by the theory sometimes approaching statistical significance, in either the growth or unemployment regressions (Table A-3) but no significance in the inflation regression. In particular, Sweden has a five percent significant coefficient on DRPT6 in the growth equation. 
3) Canada and Italy show no significant coefficients in any regressions. The case of Canada, however, is explained by the almost perfect correlation between the US and Canadian business cycle. In fact the US political dummies are statistically quite significant (five percent confidence level) in the Canadian equations! 18 Thus, it is not clear whether for the purpose of this paper Canada really provides an independent observation.

In summary, leaving aside Canada, six of the seven countries with more clearly identifiable left-right governments (that is the Us, Germany, France, the UK, Australia, and New Zealand) plus Dennark exhibit evidence of RPT effects. One bi-partisan system, Sweden, is unclear. All the multi-party parliamentary systems with large coalition governments show little sign of this type of cycle, particularly on inflation. 19

Let us now turn to PT with permanent effects: Table 11 reports the country by country results on GNP growth. For each country we have chosen the best fit between three regressions with political dummy $\operatorname{RADM}(-J) J-1,2,3$. The results for unemployment, which quite consistent with those on output, are in the Appendix (Table A-4). Only Germany does not reject the PT. For Sweden the coefficient is borderline significant, but there is no indication of partisan behavior in either unemployment (Table A-4) or inflation (Table 10). All the other countries clearly reject the theory; in several cases the coefficient on the political dummy is opposite to the theory prediction.

Table 12 reports country by country results on output for the PBC model; results on unemployment are in Table A-5. In Table 12 we have chosen the best specification between NRD4 and 6 . In four countries, Germany, Japan, UK and New Zealand the coefficient on NRD is significant. In Australia and France the coefficients have the sign inconsistent with the theory and are 
Table 11

Partisan Theory (Hibbs)

Dependent Variable: Y

(t-stacistics in parentheses)

\begin{tabular}{|c|c|c|c|c|c|c|c|c|}
\hline \multirow{2}{*}{$\frac{\text { Country }}{\text { USA }}$} & \multirow{2}{*}{$\begin{array}{c}\text { Constant } \\
-0.434 \\
(1.46)\end{array}$} & \multirow{2}{*}{ 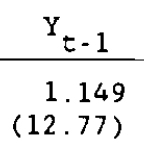 } & \multirow{2}{*}{ 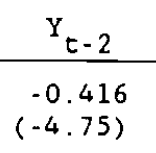 } & \multicolumn{2}{|c|}{$\operatorname{RADM}(-I)$} & \multirow{2}{*}{$\frac{Y W}{0.111}$} & \multirow{2}{*}{$\frac{\mathrm{R}^{2}}{0.78}$} & \multirow{2}{*}{$\frac{\text { D.W. }}{2.12}$} \\
\hline & & & & $\begin{array}{l}-0.162 \\
(-1.26)\end{array}$ & $(-1)$ & & & \\
\hline UK & $\begin{array}{r}0.130 \\
(0.33)\end{array}$ & $\begin{array}{r}0.542 \\
(5.51)\end{array}$ & $\begin{array}{l}-0.079 \\
(-0.84)\end{array}$ & $\begin{array}{r}0.150 \\
(0.78)\end{array}$ & $(-3)$ & $\begin{array}{r}0.299 \\
(2.97)\end{array}$ & 0.42 & 1.97 \\
\hline Austria* & $\begin{array}{r}-0.286 \\
(-0.31)\end{array}$ & $\begin{array}{r}0.857 \\
(9.00)\end{array}$ & $\begin{array}{l}-0.164 \\
(-1.75)\end{array}$ & $\begin{array}{r}0.137 \\
(0.26)\end{array}$ & $(-1)$ & $\begin{array}{r}0.464 \\
(2.20)\end{array}$ & 0.63 & 2.06 \\
\hline Denmark & $\begin{array}{l}-0.032 \\
(-0.10)\end{array}$ & $\begin{array}{r}0.780 \\
(8.24)\end{array}$ & $\begin{array}{r}-0.135 \\
(-1.47)\end{array}$ & $\begin{array}{l}-0.092 \\
(-0.61)\end{array}$ & $(-1)$ & $\begin{array}{r}0.299 \\
(3.57)\end{array}$ & 0.66 & 2.03 \\
\hline Norway & $\begin{array}{l}-0.795 \\
(2.57)\end{array}$ & $\begin{array}{r}0.870 \\
(8.98)\end{array}$ & $\begin{array}{l}-0.141 \\
(-1.43)\end{array}$ & $\begin{array}{l}-0.042 \\
(-0.41)\end{array}$ & $(-1)$ & $\begin{array}{r}0.086 \\
(1.61)\end{array}$ & 0.63 & 2.02 \\
\hline Canada & $\begin{array}{c}0.328 \\
(1.02)\end{array}$ & $\begin{array}{r}0.706 \\
(7.54)\end{array}$ & $\begin{array}{r}0.706 \\
(7.54)\end{array}$ & $\begin{array}{l}-0.244 \\
(-2.95)\end{array}$ & $(-2)$ & $\begin{array}{r}0.547 \\
(5.72)\end{array}$ & 0.71 & 1.94 \\
\hline Belgium & $\begin{array}{l}-1.910 \\
(-3.36)\end{array}$ & $\begin{array}{r}0.593 \\
(6.50)\end{array}$ & $\begin{array}{l}-0.051 \\
(-0.62)\end{array}$ & $\begin{array}{r}-0.297 \\
(-1.11)\end{array}$ & $(-3)$ & $\begin{array}{r}0.909 \\
(5.93)\end{array}$ & 0.68 & 1.98 \\
\hline Germany* & $\begin{array}{l}-0.732 \\
(-2.02)\end{array}$ & $\begin{array}{r}0.464 \\
\cdot(4.73)\end{array}$ & $\begin{array}{r}0.064 \\
(0.75)\end{array}$ & $\begin{array}{l}-0.498 \\
(-2.32)\end{array}$ & $(-3)$ & $\begin{array}{r}0.581 \\
(5.67)\end{array}$ & 0.65 & 1.91 \\
\hline Italy & $\begin{array}{c}0.238 \\
(0.37)\end{array}$ & $\begin{array}{r}0.946 \\
(9.96)\end{array}$ & $\begin{array}{l}-0.232 \\
(-2.43)\end{array}$ & $\begin{array}{r}0.057 \\
(0.14)\end{array}$ & $(-1)$ & $\begin{array}{r}0.286 \\
(2.26)\end{array}$ & 0.65 & 2.11 \\
\hline Nether 1 ands & $\begin{array}{l}-1.679 \\
(-3.37)\end{array}$ & $\begin{array}{r}0.511 \\
(5.40)\end{array}$ & $\begin{array}{r}0.149 \\
(1.72)\end{array}$ & $\begin{array}{r}0.020 \\
(0.07)\end{array}$ & $(-1)$ & $\begin{array}{r}0.837 \\
(5.97)\end{array}$ & 0.76 & 1.93 \\
\hline Australia & $\begin{array}{r}0.335 \\
(0.79)\end{array}$ & $\begin{array}{r}0.602 \\
(6.21)\end{array}$ & $\begin{array}{l}-0.007 \\
(-0.079)\end{array}$ & $\begin{array}{l}-0.126 \\
(-0.61)\end{array}$ & $(-3)$ & $\begin{array}{r}0.378 \\
(3.78)\end{array}$ & 0.55 & 2.03 \\
\hline New Zealand & $\begin{array}{l}-0.107 \\
(-0.38)\end{array}$ & $\begin{array}{r}0.867 \\
(8.69)\end{array}$ & $\begin{array}{l}-0.036 \\
(-0.36)\end{array}$ & $\begin{array}{r}0.067 \\
(0.45)\end{array}$ & $(-1)$ & $\begin{array}{r}0.142 \\
(2.17)\end{array}$ & 0.75 & 1.99 \\
\hline Finland & $\begin{array}{r}0.853 \\
(1.28)\end{array}$ & $\begin{array}{r}0.339 \\
(2.65)\end{array}$ & $\begin{array}{r}0.163 \\
(1.31)\end{array}$ & $\begin{array}{l}-0.563 \\
(-1.63)\end{array}$ & $(-1)$ & $\begin{array}{r}0.231 \\
(1.54)\end{array}$ & 0.31 & 2.05 \\
\hline France & $\begin{array}{r}0.267 \\
(0.57)\end{array}$ & $\begin{array}{r}0.337 \\
(3.17)\end{array}$ & $\begin{array}{r}0.246 \\
(2.34)\end{array}$ & $\begin{array}{r}0.294 \\
(1.06)\end{array}$ & $(-1)$ & $\begin{array}{r}0.272 \\
(2.60)\end{array}$ & 0.42 & 2.09 \\
\hline Sweden & $\begin{array}{r}0.658 \\
(1.43)\end{array}$ & $\begin{array}{c}0.461 \\
(3.76)\end{array}$ & $\begin{array}{r}-0.015 \\
(-0.12)\end{array}$ & $\begin{array}{r}-0.444 \\
(-1.69)\end{array}$ & $(-1)$ & $\begin{array}{c}0.118 \\
(1.07)\end{array}$ & 0.33 & 1.88 \\
\hline Ireland & $\begin{array}{r}-0.349 \\
(-0.30)\end{array}$ & $\begin{array}{r}0.555 \\
(3.46)\end{array}$ & $\begin{array}{r}-0.127 \\
(-0.88)\end{array}$ & $\begin{array}{r}-0.615 \\
(-1.05)\end{array}$ & $(-1)$ & $\begin{array}{c}1.123 \\
(2.82)\end{array}$ & 0.61 & 2.01 \\
\hline
\end{tabular}
*In order to malntain consistency with the RPT inflation regressions, we used ADM for
Germany and Austria. 
Table 12

political Business Cycle Theory Dependent Variable: $Y$

( $t$-statistics in parentheses)

\begin{tabular}{|c|c|c|c|c|c|c|c|}
\hline Country & Const & $Y_{t-1}$ & $Y_{t-2}$ & $\operatorname{NRD}(\mathrm{J})$ & & $\mathrm{YW}$ & $\mathrm{R}^{2}$ \\
\hline us & $\begin{array}{r}0.247 \\
(0.83)\end{array}$ & $\begin{array}{r}1.139 \\
(12.21)\end{array}$ & $\begin{array}{r}-0.384 \\
(-4.20)\end{array}$ & $\begin{array}{r}0.334 \\
(1.22)\end{array}$ & $(6)$ & $\begin{array}{r}0.101 \\
(1.31)\end{array}$ & 0.78 \\
\hline UK & $\begin{array}{r}-0.062 \\
(-0.16)\end{array}$ & $\begin{array}{r}0.517 \\
(5.03)\end{array}$ & $\begin{array}{r}-0.099 \\
(-1.05)\end{array}$ & $\begin{array}{r}0.737 \\
(1.72)\end{array}$ & (6) & $\begin{array}{r}0.317 \\
(3.16)\end{array}$ & 0.45 \\
\hline Austria & $\begin{array}{c}-0.392 \\
(-0.423)\end{array}$ & $\begin{array}{c}0.863 \\
(8.565)\end{array}$ & $\begin{array}{c}-0.168 \\
(-1.734)\end{array}$ & $\begin{array}{c}0.129 \\
(0.135)\end{array}$ & (4) & $\begin{array}{c}0.484 \\
(2.363)\end{array}$ & 0.623 \\
\hline Denmark & $\begin{array}{c}0.112 \\
(0.323)\end{array}$ & $\begin{array}{c}0.758 \\
(7.739)\end{array}$ & $\begin{array}{l}-0.150 \\
(-1.601)\end{array}$ & $\begin{array}{c}-0.105 \\
(-0.334)\end{array}$ & (6) & $\begin{array}{c}0.330 \\
(3.739)\end{array}$ & 0.657 \\
\hline Norway & $\begin{array}{c}0.964 \\
(3.043)\end{array}$ & $\begin{array}{c}0.847 \\
(8.450)\end{array}$ & $\begin{array}{c}-0.144 \\
(-1.437)\end{array}$ & $\begin{array}{c}-0.006 \\
(-0.027)\end{array}$ & $(6)$ & $\begin{array}{c}0.086 \\
(1.602)\end{array}$ & 0.613 \\
\hline Canada & $\begin{array}{r}0.401 \\
(1.24)\end{array}$ & $\begin{array}{c}0.742 \\
(7.73)\end{array}$ & $\begin{array}{c}-0.258 \\
(-3.03)\end{array}$ & $\begin{array}{r}0.081 \\
(0.25)\end{array}$ & $(6)$ & $\begin{array}{r}0.510 \\
(5.15)\end{array}$ & 0.72 \\
\hline Belgium & $\begin{array}{c}-1.774 \\
(-2.930)\end{array}$ & $\begin{array}{c}0.628 \\
(6.594)\end{array}$ & $\begin{array}{c}-0.073 \\
(-0.845)\end{array}$ & $\begin{array}{c}-0.287 \\
(-0.470)\end{array}$ & (4) & $\begin{array}{c}0.873 \\
(5.630)\end{array}$ & 0.690 \\
\hline Germany & $\begin{array}{r}-0.961 \\
(-2.37)\end{array}$ & $\begin{array}{c}0.463 \\
(4.58)\end{array}$ & $\begin{array}{c}0.051 \\
(0.58)\end{array}$ & $\begin{array}{r}0.905 \\
(2.56)\end{array}$ & (6) & $\begin{array}{r}0.555 \\
(5.47)\end{array}$ & 0.66 \\
\hline Italy & $\begin{array}{c}0.246 \\
(0.356)\end{array}$ & $\begin{array}{c}0.948 \\
(9.638)\end{array}$ & $\begin{array}{c}-0.238 \\
(-2.368)\end{array}$ & $\begin{array}{c}-0.100 \\
(-0.153)\end{array}$ & (4) & $\begin{array}{c}0.284 \\
(2.145)\end{array}$ & 0.646 \\
\hline Ne therlands & $\begin{array}{r}-1.579 \\
(-2.95)\end{array}$ & $\begin{array}{r}0.506 \\
(4.97)\end{array}$ & $\begin{array}{c}0.159 \\
(1.71)\end{array}$ & $\begin{array}{r}-0.256 \\
(-0.51)\end{array}$ & (6) & $\begin{array}{r}0.839 \\
(6.06)\end{array}$ & 0.76 \\
\hline Australia & $\begin{array}{r}0.884 \\
(1.72)\end{array}$ & $\begin{array}{r}0.569 \\
(5.71)\end{array}$ & $\begin{array}{r}0.028 \\
(0.30)\end{array}$ & $\begin{array}{r}-0.806 \\
(-2.12)\end{array}$ & (6) & $\begin{array}{r}0.327 \\
(3.39)\end{array}$ & 0.59 \\
\hline New Zealand & $\begin{array}{r}-0.253 \\
(-0.86)\end{array}$ & $\begin{array}{c}0.790 \\
(7.74)\end{array}$ & $\begin{array}{l}-0.012 \\
(0.12)\end{array}$ & $\begin{array}{c}0.780 \\
(2.885)\end{array}$ & $(4)$ & $\begin{array}{r}0.154 \\
(2.46)\end{array}$ & 0.76 \\
\hline Finland & $\begin{array}{r}0.194 \\
(0.23)\end{array}$ & $\begin{array}{c}0.431 \\
(3.27)\end{array}$ & $\begin{array}{r}0.205 \\
(1.53)\end{array}$ & $\begin{array}{r}1.071 \\
(1.28)\end{array}$ & (4) & $\begin{array}{r}0.240 \\
(1.50)\end{array}$ & 0.33 \\
\hline Sweden & $\begin{array}{r}0.405 \\
(0.80)\end{array}$ & $\begin{array}{c}0.528 \\
(4.10)\end{array}$ & $\begin{array}{c}0.024 \\
(0.19)\end{array}$ & $\begin{array}{r}0.660 \\
(1.22)\end{array}$ & (4) & $\begin{array}{c}0.096 \\
(0.81)\end{array}$ & 0.33 \\
\hline Ireland & $\begin{array}{r}-0.710 \\
(-0.55)\end{array}$ & $\begin{array}{c}0.588 \\
(3.58)\end{array}$ & $\begin{array}{l}-0.148 \\
(0.95)\end{array}$ & $\begin{array}{r}0.512 \\
(0.34)\end{array}$ & (4) & $\begin{array}{r}1.203 \\
(2.86)\end{array}$ & 0.60 \\
\hline France & $\begin{array}{c}0.498 \\
(0.95)\end{array}$ & $\begin{array}{r}0.317 \\
(2.80)\end{array}$ & $\begin{array}{r}0.270 \\
(2.52)\end{array}$ & $\begin{array}{r}-0.720 \\
(-1.28)\end{array}$ & & $\begin{array}{c}0.308 \\
(2.741)\end{array}$ & 0.42 \\
\hline Japan & $\begin{array}{c}0.147 \\
(0.350)\end{array}$ & $\begin{array}{c}0.835 \\
(8.297)\end{array}$ & $\begin{array}{c}0.031 \\
(0.322)\end{array}$ & $\begin{array}{c}0.627 \\
(1.775)\end{array}$ & (6) & $\begin{array}{c}0.124 \\
(1.343)\end{array}$ & 0.811 \\
\hline Switzerland & $\begin{array}{c}-1.201 \\
(-2.252)\end{array}$ & $\begin{array}{c}0.614 \\
(5.062)\end{array}$ & $\begin{array}{c}0.144 \\
(1.235)\end{array}$ & $\begin{array}{c}0.501 \\
(0.788)\end{array}$ & (4) & $\begin{array}{c}0.499 \\
(3.968)\end{array}$ & 0.696 \\
\hline
\end{tabular}


statistically significant (or close to $i t$ ). All the other coefficients are insignificant.

Table 13 reports the country results on inflation. Several countries, such as Denmark, France, Germany, Italy, and New Zealand show significant (ten percent or better) post-electoral upward jumps in the inflation rate. In several other countries (e.g., Japan, Norway, and UK) the sign is correct but the t-statistic does not reach a significant level. Thus, in only two countries, Germany and New Zealand, both the level of economic activity and the inflation rate follow the predictions of Nordhaus' "political business cycle" model.

5. Tests of the RPT model using Hamilton's (1989) model.

It would be interesting to derive direct measures of the dating of the business cycle in different countries and study their relation to the political variables. Obtaining estimates of the dating of the business cycle is not easy, either empirically or conceptually. The empirical problem is that, while in the United States the NBER offers already-made estimates of the peaks and troughs of economic activity, similar and comparable measures are not available for the other OECD countries. From a conceptual point of view, the recent literature on unit roots and GNP has offered a number of alternative approaches to the problem of distinguishing between trend and cyclical components of output. Most of the literature 20 is based on the assumption that GNP growth is characterized by a linear stationary process.

In a recent paper, Hamilton (1989) studies the implications of specifying the first differences of $\log$ GNP as a nonlinear stationary process. Hamilton's idea is to consider the economy as characterized by two states, a 


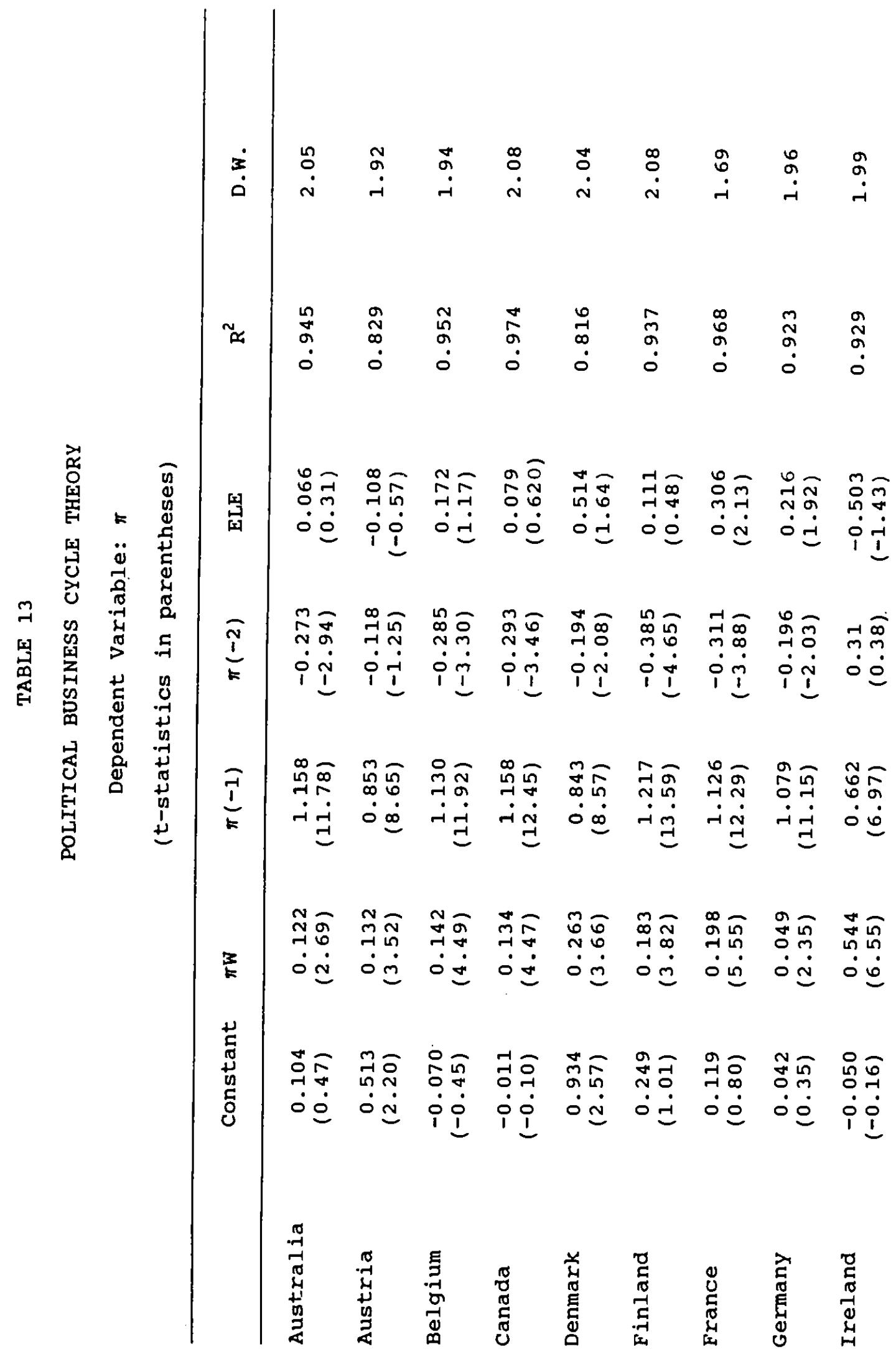




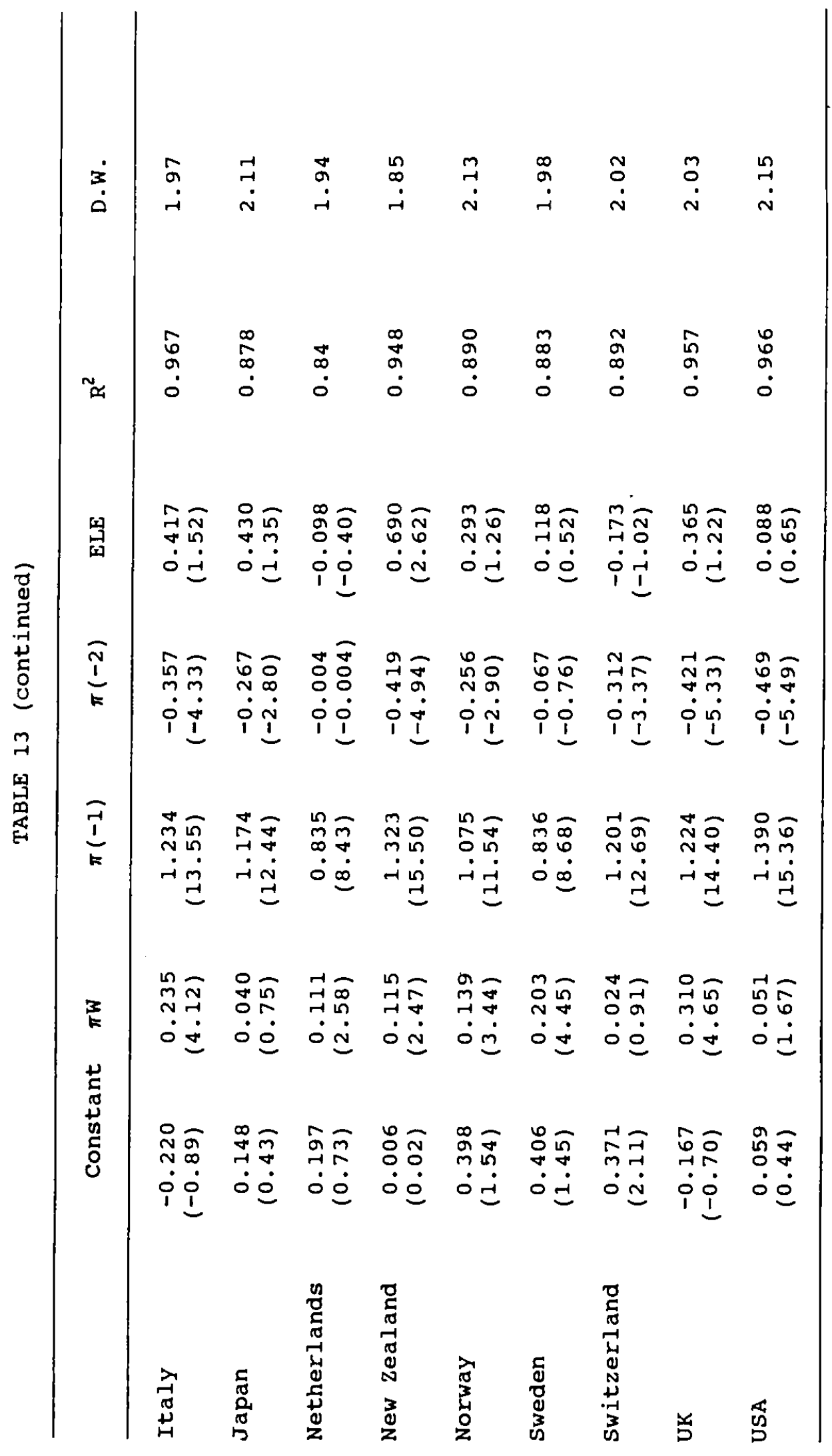


high-growth (expansion) state and a low-growth (recession) state and model the switch between these two states as being governed by a Markov process. One of the bi-products of the estimation of the model is a nonlinear filter that delivers optimal estimates of the dating of the business cycle based on past observations on output. In particular, for each quarter the filter provides an estimate of the probability that the economy is in a recession (or a boom) given the information available in the data. Using this filter, Hamilton (1989) finds that "the best statistical estimates of which quarters were historically characterized by negative growth states for the U.S. economy are remarkably similar to NBER dating of business cycles". These results suggest that one could use the same statistical approach to derive estimates of the dating of the business cycle for other OECD countries in our sample.

In this section we first derive estimates of the dating of the peaks and troughs of the business cycle for a sample of OECD economies using Hamilton's switching Markov model and then test the relation between these estimates of the business cycle and the changes in political regime suggested by the RPT model. Our use of Hamilton's approach is suggested by its success in tracking the NBER dating of the business cycle in the United States and its ability to deliver a synthetic estimate for each quarter of the probability that the economy was in a high growth (expansion) or low growth (recession) state.

Given the positive evidence in favor of the RPT model for countries with two-party systems we have considered only these countries. 21 To control for the effects of the world business cycle on the growth rate of the various economies, in our maximum likelihood estimates of Hamilton's model we take $y^{D I F}$ (defined as the difference between country i growth rate and the average 
growth rate of the major OECD countries) as the two-state variable to be explained.

Once we have obtained an estimate of the dating of the business cycle, we perform a regression of the estimated probability (PROBS) of being in a low growth state (relative to the OECD average) on a constant, the dummy for the RPT model (DRPTN) and the first lag of the dependent variable. The latter is introduced to capture the observed persistence of the probability of being in a particular state of the world. In other terms the basic regressions is:

$$
\text { PROBS }_{t}=\alpha_{0}+\alpha_{1} \text { PROBS }_{t-1}+\alpha_{2} \text { DRPTN }_{t-1}+\epsilon_{t}
$$

Table 14 reports the results of fixed-effects panel regressions of equation (6) above for 7 "bi-partisan" countries 22 . The political variable (DRPT6), used to capture the effects of the RPT model, has the correct sign and is statistically significant at the 18 confidence level.

In Table 15 we report the results of separate time series regressions for each of the seven countries considered. The coefficient on the RPT dumm (DRPT) is significant at the 108 confidence level in five of the seven countries ( $5 \%$ for United States, France and Sweden). These five countries are: United States, Germany, France, Australia and Sweden. The DRPT coefficient for the United Kingdom is significant (at the 108 level) only if we start the sample in 1970 (as discussed above). The seventh country, Canada does not show statistical significance for the RPT varlable but, as discussed in the previous section, the Canadian business cycle is mostly driven by the U.S. cycle. 
Table 14

Test of the RPT Model Using

Hamilton's Filter For the Business Cycle

Dependent Varlable: Probability of being in a low (relative to average OECD) growth state. Panel regressions on seven bi-partisan countries.

\begin{tabular}{lcc}
\hline Variable & $\begin{array}{c}\text { Estimated } \\
\text { Coefficient }\end{array}$ & t-statistics \\
\hline & & \\
Constant & 0.09 & 4.74 \\
PROBS (t-1) & 0.82 & 38.43 \\
DRPT6 & 0.046 & 3.10 \\
United states & -0.08 & -3.26 \\
Germany & 0.05 & 2.33 \\
France & 0.002 & 0.01 \\
Australla & -0.024 & -1.05 \\
Canada & -0.020 & -0.891 \\
Sweden & -0.029 & -1.14 \\
R & & \\
D.W. -1.97 & & \\
\hline
\end{tabular}


Table 15

Test of the RPT Model Using Hamilton's Filter for the Business Cycle

Dependent Variable: Probability of being in a low (relative to average OECD) growth state Time series regressions on seven bi-partisan countries. t-statistics in parentheses.

\begin{tabular}{|c|c|c|c|c|c|c|}
\hline Country & Constant & $\begin{array}{l}\text { Lagged Dep. } \\
\text { Variable }\end{array}$ & DRPTN & & $\mathrm{R}^{2}$ & D.W. \\
\hline United States & $\begin{array}{c}0.02 \\
(1.55)\end{array}$ & $\begin{array}{r}0.73 \\
(12.0)\end{array}$ & $\begin{array}{c}0.08 \\
(3.07)\end{array}$ & (a) & 0.67 & 2.08 \\
\hline Germany & $\begin{array}{c}0.14 \\
(3.31)\end{array}$ & $\begin{array}{r}0.83 \\
(16.9)\end{array}$ & $\begin{array}{c}0.06 \\
(1.59) \\
.\end{array}$ & (a) & 0.80 & 1.60 \\
\hline France & $\begin{array}{c}0.04 \\
(1.65)\end{array}$ & $\begin{array}{r}0.92 \\
(23.9)\end{array}$ & $\begin{array}{c}0.09 \\
(2.10)\end{array}$ & (b) & 0.88 & 1.83 \\
\hline Australia & $\begin{array}{c}0.11 \\
(3.04)\end{array}$ & $\begin{array}{r}0.71 \\
(10.4)\end{array}$ & $\begin{array}{c}0.10 \\
(1.83)\end{array}$ & (c) & 0.53 & 1.98 \\
\hline Canada & $\begin{array}{c}0.05 \\
(2.01)\end{array}$ & $\begin{array}{r}0.85 \\
(16.7)\end{array}$ & $\begin{array}{c}0.04 \\
(0.71)\end{array}$ & (b) & 0.73 & 1.93 \\
\hline Sweden & $\begin{array}{c}0.13 \\
(3.80)\end{array}$ & $\begin{array}{c}0.62 \\
(6.66)\end{array}$ & $\begin{array}{c}0.05 \\
(2.04)\end{array}$ & (c) & 0.51 & 1.96 \\
\hline United Kingdom & $\begin{array}{c}0.20 \\
(4.68)\end{array}$ & $\begin{array}{c}0.61 \\
(7.73)\end{array}$ & $\begin{array}{c}0.02 \\
(0.81)\end{array}$ & (b) & 0.37 & 1.95 \\
\hline United Kingdom (d) & $\begin{array}{c}0.20 \\
(4.12)\end{array}$ & $\begin{array}{c}0.58 \\
(6.25)\end{array}$ & $\begin{array}{c}0.06 \\
(1.87)\end{array}$ & (b) & 0.41 & 1.83 \\
\hline
\end{tabular}
(a) DRPT6
(b) DRPT4
(c) DRPT8
(d) 1970-1987 Sample 
6. Endogenous Elections

An empirical test of the model of $I$ to (1990a) is as follows. Define $Q_{t}$ as the probability that an election is called at time $t$ and assume that an election was held in period, and that, according to the law, an election has to be held at least every $n$ periods; Ito's model implies that $\beta_{i}>0,1: 1,2,3$ in:

$$
\mathrm{Q}_{t}=\beta_{0}+\beta_{1}(t-\tau)+\beta_{2} \mathrm{y}_{t}-\beta_{3} \pi_{t} ; \text { for } r<t \leq \tau+n
$$

Table 16 displays this probit regressions for every country in the sample in which the timing of elections is endogenous. Following Ito (1990a) the variable TL is defined as the number of quarters elapsed from the preceding elections while the other two regressors are output growth and inflation.

The results for Japan, which do not reject the theory, are consistent. with those of Ito $(1990 a, b)$. However, except possibly for Finland, no other country in the sample supports the theory; in fact, there are at least as many signs inconsistent with the theory as there are "correct" signs, even though in either case they are all insignificant.

Several different specifications of (7) were estimated in addition to that presented in Table 16. First, we used the economic variables ( $y$ and $\pi$ ) defined in difference from the world average. Second, we tried various lag structures. Third, following Ito (1990b) we used different measures of the time elapsed from the previous election; we defined $\mathrm{T} 1=\frac{r-t}{n}$ and $\mathrm{T} 2-\frac{1}{\mathrm{n}+0.001-(r-t)}$ and we tried both of them (each at a time) 
Table 16

Endogenous Timing of Elections

Probit estimation. Dependent Variable: Election

(t-statistics in parentheses)

\begin{tabular}{|c|c|c|c|c|c|}
\hline Country & const & $Y$ & $\pi$ & TL & $\mathrm{R}^{2}$ \\
\hline Australia & $\begin{array}{l}-4.182 \\
(-3.55)\end{array}$ & $\begin{array}{l}0.030 \\
(0.40)\end{array}$ & $\begin{array}{r}0.064 \\
(1.12)\end{array}$ & $\begin{array}{r}0.324 \\
(3.55)\end{array}$ & 0.24 \\
\hline Austria & $\begin{array}{l}-4.020 \\
(-3.10)\end{array}$ & $\begin{array}{r}0.021 \\
(0.48)\end{array}$ & $\begin{array}{l}-0.116 \\
(-0.98)\end{array}$ & $\begin{array}{r}0.280 \\
(3.16)\end{array}$ & 0.38 \\
\hline Belgium & $\begin{array}{l}-3.001 \\
(-3.67)\end{array}$ & $\begin{array}{c}0.022 \\
(0.40)\end{array}$ & $\begin{array}{l}-0.026 \\
(-0.31)\end{array}$ & $\begin{array}{r}0.188 \\
(3.42)\end{array}$ & 0.20 \\
\hline Canada & $\begin{array}{l}-2.447 \\
(-3.40)\end{array}$ & $\begin{array}{c}0.049 \\
(0.60)\end{array}$ & $\begin{array}{c}0.026 \\
(0.42)\end{array}$ & $\begin{array}{c}0.073 \\
(2.09)\end{array}$ & 0.07 \\
\hline Denmark & $\begin{array}{l}-5.859 \\
(-4.08)\end{array}$ & $\begin{array}{r}0.021 \\
(0.26)\end{array}$ & $\begin{array}{r}0.237 \\
(2.85)\end{array}$ & $\begin{array}{r}0.339 \\
(3.73)\end{array}$ & 0.27 \\
\hline Finland & $\begin{array}{l}-7.660 \\
(-0.32)\end{array}$ & $\begin{array}{r}0.321 \\
(1.91)\end{array}$ & $\begin{array}{r}0.057 \\
(0.73)\end{array}$ & $\begin{array}{r}0.395 \\
(2.38)\end{array}$ & 0.34 \\
\hline France & $\begin{array}{l}-2.135 \\
(-2.17)\end{array}$ & $\begin{array}{l}-0.148 \\
(-1.32)\end{array}$ & $\begin{array}{l}-0.080 \\
(-1.01)\end{array}$ & $\begin{array}{r}0.133 \\
(2.40)\end{array}$ & 0.31 \\
\hline Germany & $\begin{array}{l}-6.080 \\
(-3.53)\end{array}$ & $\begin{array}{l}-0.097 \\
(-1.00)\end{array}$ & $\begin{array}{r}0.105 \\
(0.82)\end{array}$ & $\begin{array}{r}0.387 \\
(3.22)\end{array}$ & 0.41 \\
\hline Ireland & $\begin{array}{l}-2.132 \\
(-2.16)\end{array}$ & $\begin{array}{l}-0.050 \\
(-0.94)\end{array}$ & $\begin{array}{r}0.056 \\
(1.05)\end{array}$ & $\begin{array}{c}0.028 \\
(0.56)\end{array}$ & 0.03 \\
\hline Italy & $\begin{array}{l}-7.515 \\
(-3.19)\end{array}$ & $\begin{array}{r}0.041 \\
(0.42)\end{array}$ & $\begin{array}{r}0.107 \\
(1.61)\end{array}$ & $\begin{array}{r}0.359 \\
(3.06)\end{array}$ & 0.33 \\
\hline Japan * & $\begin{array}{l}-7.123 \\
(-3.34)\end{array}$ & $\begin{array}{r}0.180 \\
(2.45)\end{array}$ & $\begin{array}{l}-0.139 \\
(1.31)\end{array}$ & $\begin{array}{r}0.487 \\
(3.16)\end{array}$ & 0.38 \\
\hline Ne therlands & $\begin{array}{l}-2.649 \\
(-3.59)\end{array}$ & $\begin{array}{l}-0.063 \\
(-1.30)\end{array}$ & $\begin{array}{l}-0.026 \\
(-0.35)\end{array}$ & $\begin{array}{r}0.149 \\
(2.97)\end{array}$ & 0.22 \\
\hline New Zealand & $\begin{array}{r}-163.97 \\
(-0.04)\end{array}$ & $\begin{array}{c}1.67 \\
(0.66)\end{array}$ & $\begin{array}{c}0.108 \\
(0.47)\end{array}$ & $\begin{array}{l}13.939 \\
(0.04)\end{array}$ & 0.91 \\
\hline UK & $\begin{array}{l}-2.304 \\
(-2.90)\end{array}$ & $\begin{array}{l}-0.172 \\
(-1.50)\end{array}$ & $\begin{array}{l}-0.006 \\
(-0.13)\end{array}$ & $\begin{array}{r}0.117 \\
(2.66)\end{array}$ & 0.21 \\
\hline
\end{tabular}

* For Japan, the 1980:2 election was dummied out as in Ito (1990 a). 
instead of $(r-t)$ in (7). 23 The results of all these regressions (available upon request) confirm the results of Table 16.

These negative results should not be interpreted as a rejection of the basic, insightful idea of strategic choice of election timing, for several reasons. First of all the economy is only one of the variables which may influence the choice of calling an election. A major success in foreign policy, or various events affecting negatively the public image of the opposition, may be strategically used by the incumbent. A careful study for each country of the interaction of economic and non-economic factors would be very valuable but goes beyond the scope of the present paper. Second, the model of strategic timing of election is probably more applicable to countries, like Japan or the U.K., with unified control rather than coalition governments. In fact, different members of coalition governments may disagree on the optimal time for calling an election, since their expectations on their relative popularity may diverge. Thus, in this institutional structure, the decision about when to call an election, appears much more as the result of a non cooperative game between coalition members rather than an optimal strategic decision of a unified government. Finally, one may argue that, particularly for the cases of weak coalition governments, the reverse causation may be also important: governments collapse and elections have to be called early, when the economy is doing poorly and the coalition cannot agree on what to do (see Robertson (1983)). More generally, in countries with large coalitions and frequent elections (such as Belgium, Italy, the Netherlands) coalition collapses are probably the result of more complex politico-economic factors than the short run state of the economy. 


\section{Conclusions}

The most interesting result of this paper is that the more recent models of political cycles significantly outperform their predecessors. The rational "opportunistic" model by Rogoff and Sibert (1988) and the rational partisan model by Alesina (1987) are consistent with the overall pattern of results for several countries.

The main finding of this paper can be summarized as follows:

1) With the exception of three countries (Germany and New Zealand and, possibly, Japan), we found no evidence of a systematic opportunistic cycle of the Nordhaus type either for output or unemployment.

2) The opportunistic political business cycle model with endogenous timing of elections is rejected in every country, with the exception of Japan.

3) An electoral cycle on the inflation rate, consistent with the models of budget cycles of Rogoff and sibert (1988), was found.

4) The implications of the "rational partisan theory" are consistent with the empirical evidence particularly for a subset of countries with a bi-partisan system or at least with more clearly identifiable political changes from left to right and vice-versa. This theory is less applicable, and in fact tends to fail, in countries with large coalition governments with frequent government collapses.

5) The "partisan theory" with permanent effects on output and unemployment is generally rejected.

Thus, a political cycle which seems to appear fairly consistently in several countries is the following: left wing government expand the economy when elected; for a while (about 2 years) they succeed, then inflation expectations adjust and the economy returns to its natural rate of growth. At 
this point, left wing governments are trapped into the time consistent equilibrium with an inflation bias á la Barro and Gordon (1983b). Note that, when left wing governments approach the new election in this high inflation, they may try to reduce the latter, particularly if inflation is perceived as the main economic problem of the time (Lindbeck (1976)). When right wing governments are elected they fight inflation, causing a recession or a growth slowdown. Later in their term, the economy goes back at its natural rate of growth and inflation remains low.

Two explanations can account for the relatively little evidence of a Nordhaus type opportunistic cycle on growth and unemployment: First, a "rational" electorate imposes a limit on this behavior; an excessive attempt to pursue opportunistic policies may be perceived as counterproductive by policymakers. Second, it may be quite difficult to create expansions precisely timed before elections.

However, the results on post-electoral inflation increase may signal the occurrence of pre-electoral opportunistic budget policies. Alesina (1989) presents some qualitative evidence which suggests that budget deficits tend to fncrease in election years in several countries. Evidence on budget cycles in the US is discussed in Tufte (1978), Alesina (1988a), and Nordhaus (1989). Preelectoral fiscal "favors" to key constituencies may be electorally very useful and easy to implement, relative to an attempt to increase the rate of growth of GNP.

These opportunistic monetary and fiscal policies may very well coexist with the partisan cycles found in the data. Even "partisan" politicians prefer to be in office, rather than out; by being in office they can implement their desired goals. Thus, they may engage in short term pre-electoral 
opportunistic monetary and fiscal policies to enhance their chances for reelection. Further research on a multi-country sample could shed more light on this issue: in fact our results on inflation suggest that pre-electoral manipulations of monetary and fiscal policy instruments may be the rule rather than the exception. 
Footnotes

1. Furthermore, Nordhaus' "political business cycle" model did not receive a convincing empirical support. Soon after the publication of Nordhaus' paper McCallum (1978) and Paldam (1979) presented negative empirical results for the U.S. and OECD economies respectively. More favorable results are shown by Tufte (1978) on a sample including a few American elections.

2. By Okun's law the same model could be written in terms of the unemployment rate.

3. To be precise, Nordhaus (1975) assumes that policymakers control aggregate demand and, indirectly, inflation. This difference is inessential and, in fact, the more recent models simplify the analysis by assuming that the government has direct control over the inflation rate.

4. Nordhaus' (1975) model predicts that inflation should increase before the election. However, given time lags between the effects of aggregate demand policies on output and inflation, it is possible to construct a model of the Nordhaus type in which inflation increases immediately after, rather than before the election. (See Lindbeck (1976)).

5. In Cukferman and Meltzer (1986) the asymmetry of Information is related to the knowledge of the realization of a random shock to the economy.

6. Formally, the degree of competence is modelled by adding a term in equation ( 1 ) which changes over time and is known by the policymaker but becomes known to the voter only with a lag. For an explicit test of this "competence" model on United States data see Alesina, Londregan and Rosenthal (1990). 
7. Note that Nordhaus' PBC and Hibbs' PT can coexist. If one assumes that politicians are both opportunistic and partisan and voters are retrospective as implied by A.5, one obtains a "weaker" form of PT which incorporates elements of pre-electoral opportunistic behavior. See Frey and Schneider (1978) and Nordhaus (1989).

8. In the regressions for the seven countries included in the creation of the proxy for the OECD averages, we have used different proxies which exclude the country in the left-hand side of the regression.

9. A priori, the correct dynamic specification of the model could differ across countries but in country by country regressions we found that the same AR specification is the best for almost all the countries in the sample. However, even if the same AR specification applies to each country, the estimates of the coefficients on the dynamic part of the model could differ across countries and suggest the use of a variable-slopes and variableintercepts model. Given the significant loss of degrees of freedom involved, this procedure was not adopted. Furthermore, country specific results are discussed in Section 4.

10. Ellis and Thoma (1989) present an extension of the partisan model for the case of endogenous timing of elections.

11. It is known that in the case of dynamic fixed-effects panel models such as the one estimated here, the correlation between the error term and the lagged dependent variables might lead to potentially biased and inconsistent estimates of the parameters of the model (see Hsiao (1986)). The problem is quite serious in panel sets where the number of agents (N) considered is large but the number of times series observations $(T$ ) is small (data over a very short period of time). In that case the maximum likelihood estimator of the 
dynamic model is inconsistent even if the number of agents becomes very large (see Anderson and Hsiao (1982) and Nickell (1981)). The solution to this problem is to use instrumental-variable methods such as those suggested by Bhargava and Sargan (1983) and Pakes and Griliches (1984). Our panel data set, however, does not suffer of the above problem because of the use of a long time series (usually 112 data points). As observed by Hsiao (1986), in the case where the time period $T$ over which data are available is large, as in our model, the parameter estimates of the standard fixed-effects dynamic model are consistent.

12. Analogous results on the political dummy available are obtained by using as a dependent variable the difference between domestic and world growth.

13. The variable $U_{t}^{D I F}$ shows in fact a high level of persistence. Given this persistence, even a "temporary" policy shock as the one captured by the dummy DPRT6 has rather persistent effects.

14. One could add ofl prices to the equation but the inclusion of the world inflation variable already proxies for this role of oil shocks.

15. The significance of the coefficients of the political dummies in Tables 1,2 and 3 does not result from the influence of any single country. If one drops from the pull any of the 16 countries and retain the other 15 , the coefficlents on the political dummies remain significant. These results are available.

16. These results are avallable upon request.

17. An even more extreme version of this model of voters' myopla would imply that they ignore the influence of the world economy on their countries' performance and thus politicians simply attempt to expand their economies, regardless of the world economy. This hypothesis can be tested running the 
same regressions of Tables 6,7 without correcting for the effect of the world economy. The results (available upon request) show no support for the $P B C$.

18. Results are available upon request.

19. Our results regarding the RPT theory on output growth and unemployment are confirmed by another set of regressions in which we used a distributed lag of the variable representing the changes in partisan regime, instead of the DRPT variable. For the countries in which tables 9 and $A-3$ show a significant DRPT effect we find that an F-test on the distributed lag variable rejects the null hypothesis that the sum of all coefficients is equal to zero. These results are available upon request.

20. See Nelson and Plosser (1982), Campbell and Mankiw (1987), Watson (1986), Clark (1987), King, Plosser, Stock and Watson (1987).

21. Given our results in Table 9, Hamilton's tests on the other countries are not likely to support the theory.

22. New Zealand is excluded from the sample because of lack of quarterly data.

23. Tl is simply the number of quarters elapsed from the previous election as a ratio of the maximum number of quarters between elections (i.e., $n$ ). T2 is constructed such that it assumes a very high value (1000) when elections are not anticipated. The idea is that the economy has no influence on the timing in these cases (see Ito (1990b)). 


\section{REFERENCES}

Alesina, Alberto (1990): "Evaluating Rational Partisan Business Cycle Theory: A Response," unpublished.

Alesina, Alberto (1989): "Politics and Business Cycles in Industrial Democracies," Economic Policy, No. 8. (1988a): "Macroeconomics and Politics," NBER Macroeconomic Annual, M.I.T. Press, 13-52. (1988b): "Credibility and Policy Convergence in a Two-Party System with Rational Voters," American Economic Review, September, 796-806. (1987): "Macroeconomic Policy in a Two-Party System as a Repeated

Game," Quarterly Journal of Economics 102, August, 651-78. and Howard Rosenthal (1989): "Ideological Cycles in Congressional Elections and the Macroeconomy," American Political Science Review, June. , John Londregan and Howard Rosenthal (1990): "A Political-Economy

Model of the United States," unpublished. and Jeffrey Sachs (1988): "Political Parties and the Business

Cycle in the United States, 1948-1984." Journal of Money, Credit and Banking 20, February, 63-82.

Alt, James (1985): "Political Parties, World Demand, and Unemployment: Domestic and International Sources of Economic Activity," American Political Science Review 79, December, 1016-1040.

Alvarez, Michael, Geoffrey Garret and Peter Lange (1989): "The Political Economy of Macroeconomic Performance: The Advanced Industrial Democracies, 1967-1986," unpublished. 
Anderson, T.W., and C. Hsiao (1982): "Formulation and Estimation of Dynamic Models Using Panel Data," Journal of Econometrics 18, 47-82.

Banks, Arthur (1987): Political Handbook of the World.

Barro, Robert and David Gordon (1983a): "Rules, Discretion, and Reputation in a Model of Monetary Policy," Journal of Monetary Economics 12, July, 10122. and (1983b): "A Positive Theory of Monetary Pollcy in a Natural Rate Model," Journal of Political Economy 31(August), 589-610. Bhargava, A., and J.D. Sargan (1983): "Estimating Dynamic Random Effects Models from Panel Data Covering Short Time Periods," Econometrica 5l, $1635-59$.

Blanchard, Olivier and Lawrence Summers (1986): "Hysteresis and the European Unemployment Problem" NBER Macroeconomic Annual 1986.

Campbell, John Y., and N. Gregory Mankiw (1987): "Permanent and Transitory Components in Macroeconomic Fluctuations," American Economic Review Papers and Proceedings $77,111-117$.

Clark, Peter K. (1987): "The Cyclical Component of U.S. Economic Activity," Quarterly Journal of Economics 102, 797-814.

Ellis, Christopher and Mark Thoma (1989): "Partisan Effects When the Election Time Is Endogenous," unpublished.

Frey, Bruno and Frederich Schneider. (1978): "An Empirical Study of PoliticoEconomic Interaction in the United States," The Review of Economics and Statistics 60 , May, 174-83.

Hamilton, James (1989): "A New Approach to the Economic Analysis of NonStationary Time Series and the Business Cycle," Econometrica, March, 35784. 
Hibbs, Douglas (1977): "Political Parties and Macroeconomic Policy," The American Political Science Review 7. December, 1467-1487. (1987): The American Political Economy, Cambridge, MA: Harvard University Press.

Hsiao, C. (1986): Analysis of Panel Data, Cambridge University Press. Ito, Takatoshi (1990a): "The Timing of Elections and Political Business Cycles in Japan," Journal of Asian Economics 1(1), 135-146. (1990b): "International Impacts on Domestic Political Economy: A Case of Japanese General Elections," unpublished.

King, Robert, Charles Plosser, James Stock, and Mark Watson (1987): "Stochastic Trends and Economic Fluctuations," NBER Working Paper No. 2229.

Kydland, Finn and Edward Prescott (1977): "Rules Rather Than Discretion: The Inconsistency of Optimal Plans," Journal of Political Economy 85(June), 473-490.

Lindbeck, Assar (1976): "Stabilization Policies in Open Economies with Endogenous Politicians," American Economic Review, Papers and Proceedings, May, 1-19.

McCallum, Bennett (1978): "The Political Business Cycle: An Empirical Test," Southern Economic Journal 44, January, 504-515.

Nelson, Charles R., and Charles I. Plosser (1982): "Trends and Random Walks in Macroeconomic Time Series: Some Evidence and Implications, "Journal of Monetary Economics 10, 139-162.

Nickell, S. (1981): "Biases in Dynamic Models with Fixed Effects," Econometrica 49, 1399-416. 
Nordhaus, William (1989): "Alternative Models to Political Business Cycles," Brookings Papers on Economic Activity 1989, No. 2.

(1975): "The Political Business Cycle," Review of Economic Studies 42, Apri1, 169-190.

Paldam, Martin (1989a): "Politics Matter After All: Testing Alesina's Theory of RE Partisan Cycles" Aarhus University Working Paper.

(1989b): "Politics Matter After All: Testing Hibbs' Theory of Partisan Cycles" Aarhus University Working Paper. (1979): "Is There An Electoral Cycle?" Scandinavian Journal of Economics.

Pakes, Ariel, and Zvi Griliches (1984): "Estimating Distributed Lags in Short Panels with an Application to the Specification of Depreciation Patterns and Capital Stock Constructs," Review of Economic Studies 51, 243-62.

Persson, Torsten and Guido Tabellini (1990): "Macroeconomic Policy, Credibility and Politics," manuscript.

Robertson, John (1983) "Inflation, Unemployment and Government Collapse: A Poisson Application," Comparative Political Studies.

Rogoff, Kenneth (1990): "Equilibrium Political Budget Cycles," American Economic Review, 80 (March). and Anne Sibert (1988): "Equilibrium Political Business Cycles," Review of Economic Studies 55, January, 1-16.

Sheffrin, Steven (1989): "Evaluating Rational Partisan Business Cycle Theory," Economics and Politics 1, 3, November, 239-59.

Terrones, Marco (1987): "Macroeconomic Policy Cycles under Alternative Electoral Structures: A Signaling Approach," unpublished. 
Tufte, Edward (1978): Political Control of the Economy, Princeton, N.J.: Princeton University Press.

Watson, Mark W. (1986): "Univariate Detrending Methods with Stochastic Trends," Journal of Monetary Economics 18, 49-75. 
APPENDIX

Table A-1

Description of Data

Inflation: Inflation is obtained as: $\pi_{t}=\left[\left(P_{t}-P_{t-4}\right) / P_{t-4}\right] \times 100$ where $P_{t}$ is the Consumer Price Index in quarter $t$. For all countries the sample is 1960:1, 1987:4, and CPI is taken from line 64 of IMF-IFS.

Output and Unemployment: Country-by-country sample and sources.

Note: Countries which use other measures of GDP do so because real quarterly GDP is not available.

AUSTRALIA: $\quad$ GDP - real quarterly GDP from OECDMEI (1960:1-1987:4). Unemployment - unemployment rate - adjusted - OECDMEI (1965:1-1987:4).

AUSTRIA:

GDP - real quarterly GDP from IMF-IFS (1960:1-1987:4). Unemployment - unemployment rate - total - adjusted OECDMEI (1969:1-1987:4).

BELGIUM:

GDP - quarterly Industrial Production from OECDMEI (1960:1$1987: 4$ ).

Unemployment - unemployment rate - total insured adjusted - OECDMEI (1960:1-1987:4).

CANADA:

GDP - real quarterly GDP from IMF-IFS (1960:1-1987:4). Unemployment - unemployment rate - total - adjusted OECDMEI (1960:1-1987:4).

DENMARK :

GDP - real ANNUAL GDP from IMF-IFS (1960:1-1987:4)

(converted into quarterly data by assuming that quarter-toquarter annual change corresponds to year-to-year change). Unemployment - unemployment rate - registered unemployed - adjusted - OECDMEI (1970:1-1987:4).

FINLAND :

GDP - real quarterly GDP from IMF-IFS (1970:1-1987:4). Unemployment - unemployment rate - total - adjusted OECDMEI (1960:1-1987:4).

FRANCE :

GDP - real quarterly GDP from IMF-IFS (1965:1-1987:4). Unemployment - unemployment rate - total - adjusted OECDMEI ( $1967: 1-1987: 4)$.

GERMANY :

GDP - real quarterly GDP from IMF-IFS (1960:1-1987:4). Unemployment - unemployment rate - adjusted - OECDMEI (1965:1.1987:4).

IRELAND :

GDP - quarterly Industrial Production from OECDMEI (1975:1$1986: 4)$.

Unemployment - unemployment rate - adjusted - OECDMEI (1975:1-1987:4). 
ITALY :

JAPAN :

NETHERLANDS :

NEW ZEALAND :

NORWAY :

SWEDEN :

SWITZERLAND:

UK:

USA :

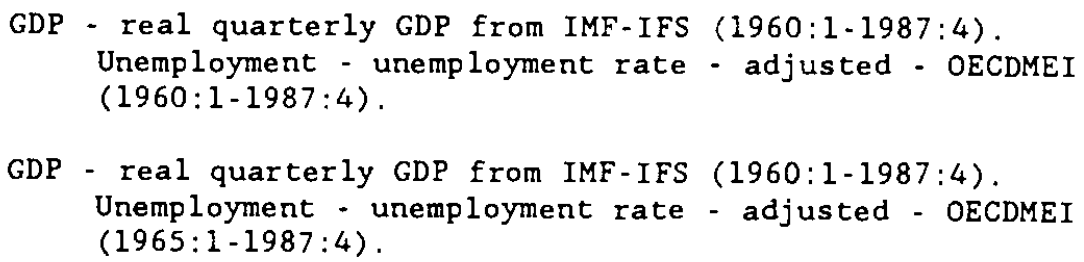

GDP - quarterly Industrial Production from OECDMEI (1960:11987:4).

Unemployment - unemployment rate - registered unemployed - OECDMEI (1971:1-1987:4), no adjusted available.

GDP - real ANNUAL GDP from IMF-IFS. (1960:1-1987:4)

(converted into quarterly data by assuming that quarter-toquarter annual change corresponds to year-to-year change). Unemployment - not available.

GDP - real ANNUAL GDP from IMF-IFS (1960:1-1987:4) (converted into quarterly data by assuming that quarter-toquarter annual change corresponds to year-to-year change). Unemployment - unemployment rate - adjusted - OECDMEI $(1972: 1-1987: 4)$.

GDP - real quarterly GDP from IMF-IFS (1969:1-1987:4). Unemployment - unemployment rate - total insured adjusted - OECDMEI (1969:1-1983:4).

GDP - real quarterly GDP form IMF-IFS (1967:1-1986:4). Unemployment - ratio of total unemployed to labor force - adjusted - OECDMEI (1974:4-1987:3).

GDP - real quarterly GDP form IMF-IFS (1960:1-1987:4). Unemployment - unemployment rate - registered. civilian - adjusted - OECDMEI (1960:1-1987:4).

GDP - real quarterly GDP from IMF-IFS (1960:1-1987:4). Unemployment - unemployment rate - total - adjusted. OECDMEI (1960:1-1987:4). 
Table A-2

Election and Regime Change

E - Election; CH L = Change Left; Ch R - Change Right

AUSTRALIA: Endogenous Timing, 3 YRS AUSTRIA: Endogenous Timing, 4 YRS

$\begin{array}{lllllllll}1961: 4 & \text { E } & \text { RIGHT } & \text { a } & 1959: 2 & \text { E } & \text { RIGHT c } \\ 1963: 4 & \text { E } & & & 1962: 4 & \text { E } & & \\ 1966: 4 & \text { E } & & & 1966: 1 & \text { E } & \text { CH R } & \\ 1969: 4 & \text { E } & & & 1970: 1 & \text { E } & \text { CH L } & \\ 1972: 4 & \text { E } & \text { CH L } & & 1971: 4 & \text { E } & & \text { (*) } \\ 1974: 2 & \text { E } & & \text { (*)b } & 1975: 4 & \text { E } & & \\ 1975: 4 & \text { E } & \text { CH R } & & 1979: 2 & \text { E } & & \\ 1977: 4 & \text { E } & & & 1983: 2 & \text { E } & \text { CH R } & \text { c } \\ 1980: 4 & \text { E } & & & 1986: 4 & \text { E } & \text { CH R } & \\ 1983: 1 & \text { E } & \text { CH L } & & & & & \\ 1984: 4 & \text { E } & & \text { (*) } & & & & & \end{array}$

BELGIUM: Endogenous Timing, 4 YRS CANADA: Endogenous Timing, 5 YRS

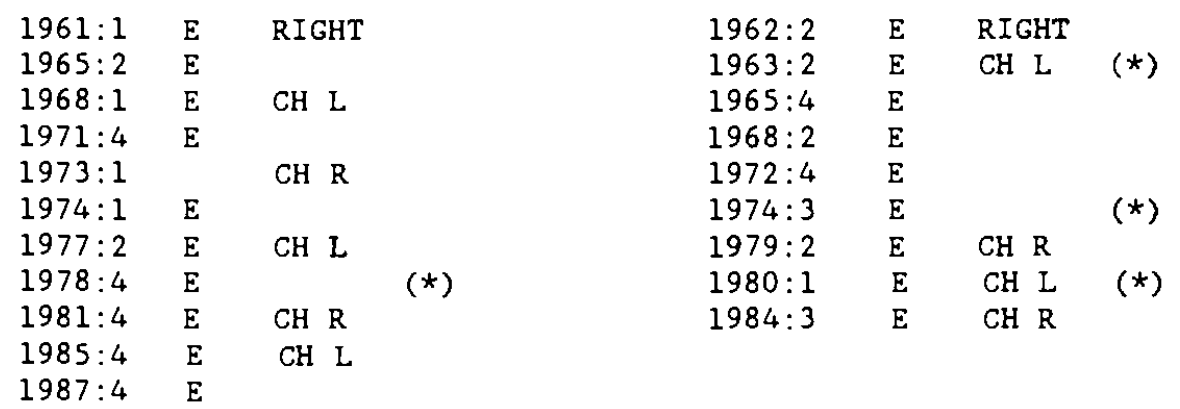

DENMARK: Endogenous Timing, 4 YRS FINLAND: Endogenous Timing, 4 YRS

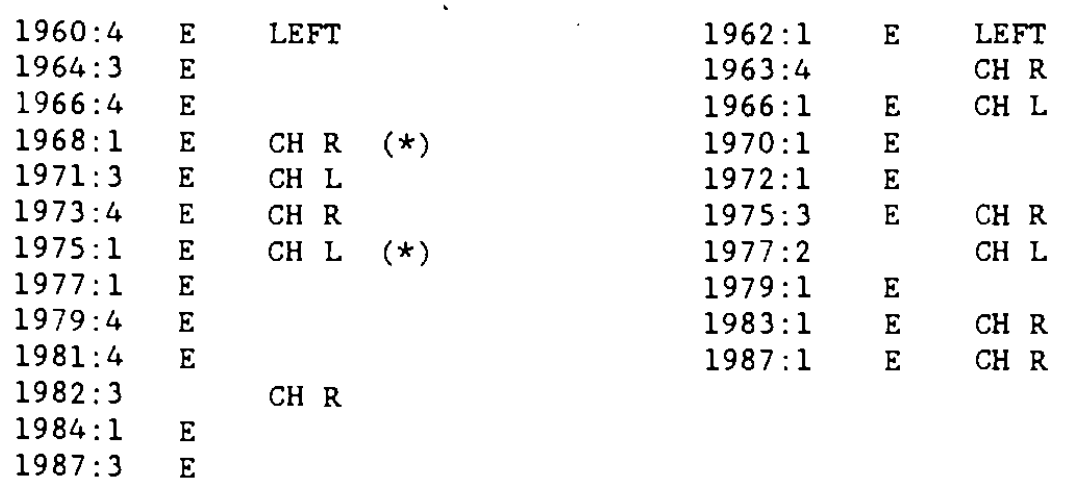


Table A-2 (continued)

FRANCE: Endogenous Timing, 5 YRS

$\begin{array}{lll}1962: 4 & \text { E } & \text { RIGHT } \\ 1967: 1 & \text { E } & \\ 1968: 2 & \text { E } & \\ 1973: 1 & \text { E } & \\ 1978: 1 & \text { E } & \\ 1981: 2 & \text { E } & \text { CH L } \\ 1984: 3 & & \text { CH R } \\ 1986: 1 & \text { E } & \text { CH R }\end{array}$

IRELAND: Endogenous Timing, 5 YRS

\begin{tabular}{|c|c|c|}
\hline $1961: 4$ & $E$ & RIGHT \\
\hline $1965: 2$ & $\mathrm{E}$ & \\
\hline $1969: 2$ & $E$ & \\
\hline 1973:1 & $E$ & $\mathrm{CH} \mathrm{L}$ \\
\hline $1977: 2$ & $\mathrm{E}$ & $\mathrm{CH} \mathrm{R}$ \\
\hline $1981: 2$ & $\mathrm{E}$ & $\mathrm{CH} \mathrm{L}$ \\
\hline $1982: 1$ & $E$ & $\mathrm{CH} \mathrm{R}$ \\
\hline $1982: 4$ & $E$ & $\mathrm{CH} \mathrm{L}$ \\
\hline $1987: 1$ & $E$ & \\
\hline
\end{tabular}

JAPAN: Endogenous Timing, 4 YRS

$\begin{array}{lll}1960: 4 & E & \text { RIGHT } \\ 1963: 4 & E & \\ 1967: 1 & E & \\ 1969: 4 & E & \\ 1972: 4 & E & \\ 1976: 4 & E & \\ 1979: 4 & E & \\ 1980: 2 & E & \\ 1983: 4 & E & \\ 1986: 3 & E & \end{array}$

GERMANY: Endogenous Timing, 4 YRS

$\begin{array}{llll}1961: 3 & \text { E } & \text { RIGHT } \\ 1965: 3 & \text { E } & & \\ 1966: 4 & & \text { CH L } & \text { C } \\ 1969: 3 & \text { E } & \text { CH L } & \\ 1972: 4 & \text { E } & \text { CH R } & \\ 1976: 4 & \text { E } & & \\ 1980: 4 & \text { E } & & \\ 1982: 4 & & \text { CH R } & \\ 1983: 1 & \text { E } & & \\ 1987: 1 & \text { E } & & \end{array}$

ITALY: Endogenous Timing, 5 YRS

$\begin{array}{lll}1962: 4 & & \text { RIGHT } \\ 1963: 2 & \text { E } & \text { CH L } \\ 1968: 2 & \text { E } & \\ 1972: 2 & \text { E } & \\ 1974: 4 & & \text { CH R } \\ 1976: 2 & \text { E } & \text { CH L } \\ 1979: 2 & \text { E } & \\ 1983: 2 & \text { E } & \\ 1987: 2 & \text { E } & \end{array}$

NETHERLANDS: Endogenous Timing, 4 YRS

$\begin{array}{lll}1959: 1 & \text { E } & \text { RIGHT } \\ 1963: 2 & \text { E } & \\ 1965: 2 & & \text { CH L } \\ 1967: 1 & \text { E } & \text { CH R } \\ 1971: 1 & \text { E } & \\ 1972: 4 & \text { E } & \\ 1973: 2 & & \text { CH L } \\ 1977: 2 & \text { E } & \\ 1977: 4 & & \text { CH R } \\ 1981: 2 & \text { E } & \text { CH L } \\ 1982: 3 & \text { E } & \text { CH R } \\ 1986: 2 & \text { E } & \end{array}$

(*)

(*) 
Table A-2 (continued)

NEW ZEALAND: Endogenous Timing, 3 YRS NORWAY: Exogenous Timing, 4 YRS

$\begin{array}{llllll}1960: 4 & \text { E } & \text { RIGHT } & 1961: 3 & \text { E } & \text { LEFT } \\ 1963: 4 & \text { E } & & 1965: 3 & \text { E } & \text { CH R } \\ 1966: 4 & \text { E } & & 1969: 3 & \text { E } & \\ 1969: 4 & \text { E } & & 1971: 4 & & \text { CH L } \\ 1972: 4 & \text { E } & \text { CH L } & 1972: 4 & & \text { CH R } \\ 1975: 4 & \text { E } & \text { CH R } & 1973: 3 & \text { E } & \text { CH L } \\ 1978: 4 & \text { E } & & 1977: 3 & \text { E } & \\ 1981: 4 & \text { E } & & 1981: 3 & \text { E } & \text { CH R } \\ 1984: 3 & \text { E } & \text { CH L } & 1985: 3 & \text { E } & \\ 1987: 3 & \text { E } & & 1986: 2 & & \text { CH L }\end{array}$

SWEDEN: Exogenous Timing, 3 YRS SWITZERLAND: Exogenous Timing, since late $60 \mathrm{~s}$, constitutional reform

4 YRS

$\begin{array}{llllll}1960: 3 & \text { E } & \text { LEFT } & 1959: 4 & \text { E } & \text { RIGHT } \\ 1964: 3 & \text { E } & & 1963: 4 & \text { E } & \\ 1968: 3 & \text { E } & & 1967: 4 & \text { E } & \\ 1970: 3 & \text { E } & & 1971: 4 & \text { E } & \\ 1973: 3 & \text { E } & & 1975: 4 & \text { E } & \\ 1976: 3 & \text { E } & \text { CH R } & 1979: 4 & \text { E } & \\ 1979: 3 & \text { E } & & 1983: 4 & \text { E } & \\ 1982: 3 & \text { E } & \text { CH L } & 1987: 4 & \text { E } & \\ 1985: 3 & \text { E } & & & & \end{array}$

UK: Endogenous Timing, 5 YRS

$\begin{array}{ll}1959: 4 & E \\ 1964: 4 & E \\ 1966: 1 & E \\ 1970: 2 & E \\ 1974: 1 & E \\ 1974: 3 & E \\ 1979: 2 & E \\ 1983: 2 & E \\ 1987: 2 & E\end{array}$

a RIGHT or LEFT indicates the type of government in power at the beginning of the sample which is $1959: 1$. We also indicate for each country whether elections dates are endogenous or exogenous and the official number of years between two elections.

b Elections denoted with an asterisk "*" are not included in tests of the political business cycle theory because they are too close (less than two years) to previous elections. They are however included in tests of the opportunistic endogenous election model.

c Both Germany and Austria had grand coalitions of Left and Right parties. Thus, a finer administration variable was used in the RPT inflation and partisan (Hibbs) regressions. This also explains the occurence of a rightward shift from an already central Right leaning party. 
Table A-2 (continued

Source: Election Dates are obtained from Banks (1989); dates of changes of government and their classification of "Right" and "Left" are obtained from Alt (1985) and Banks (1989). 


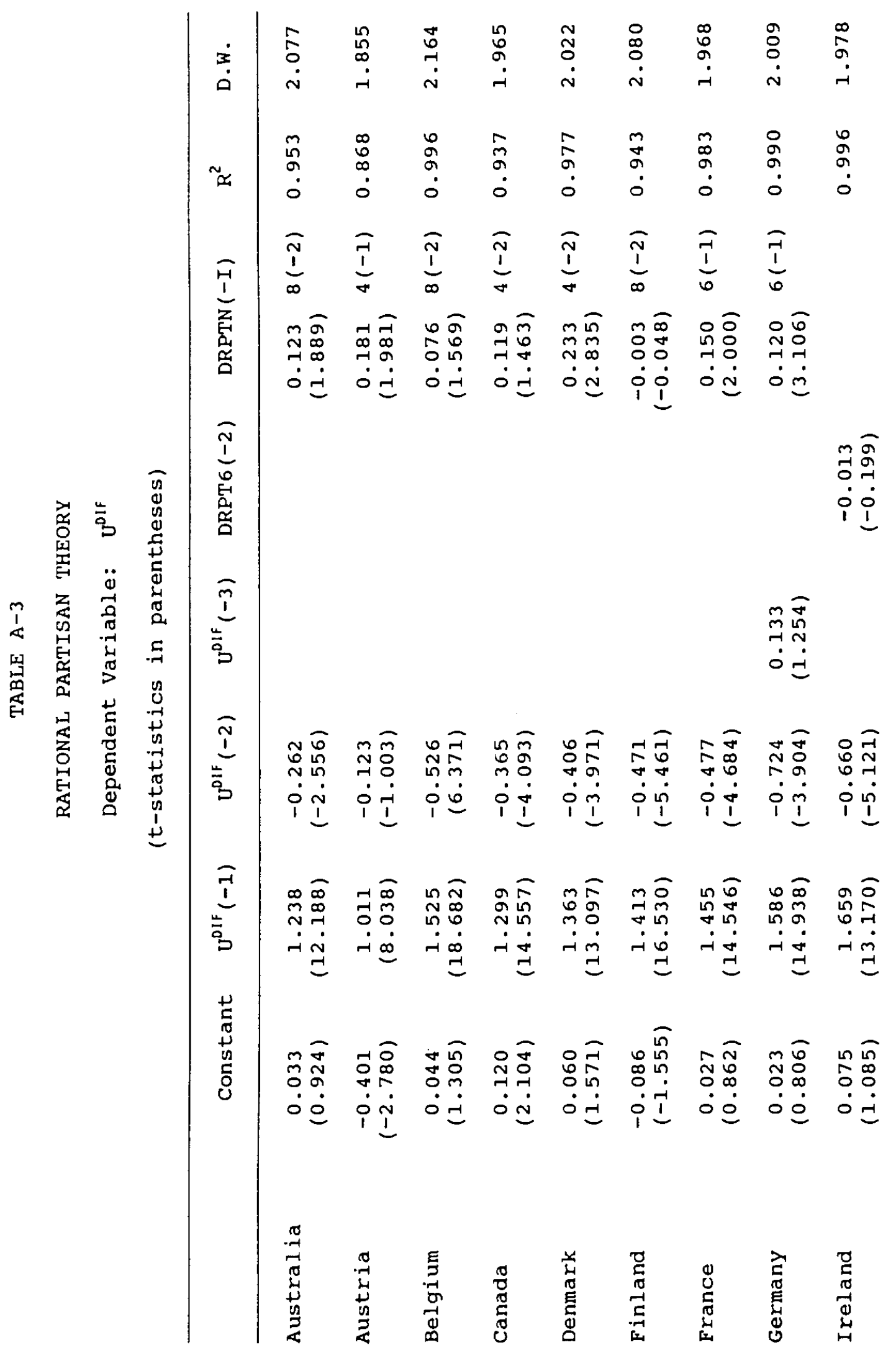




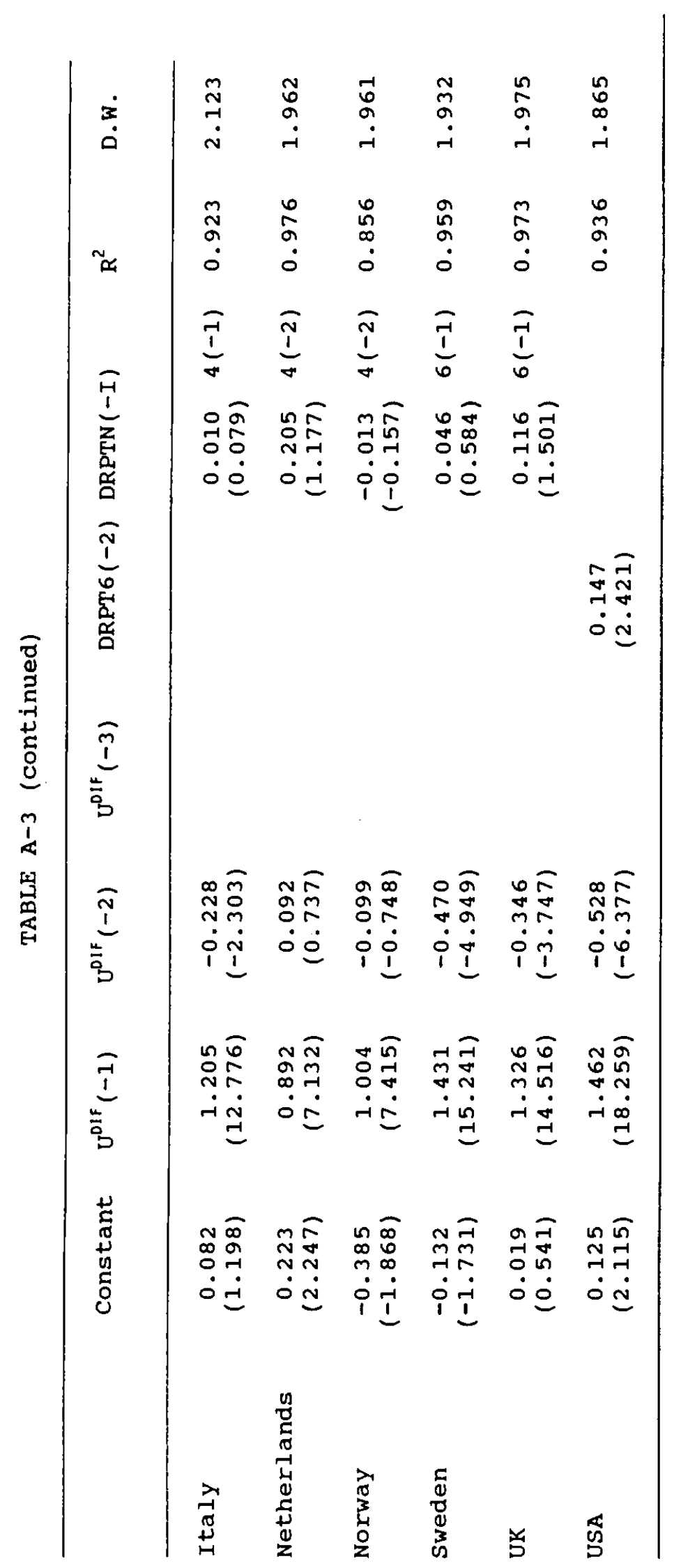




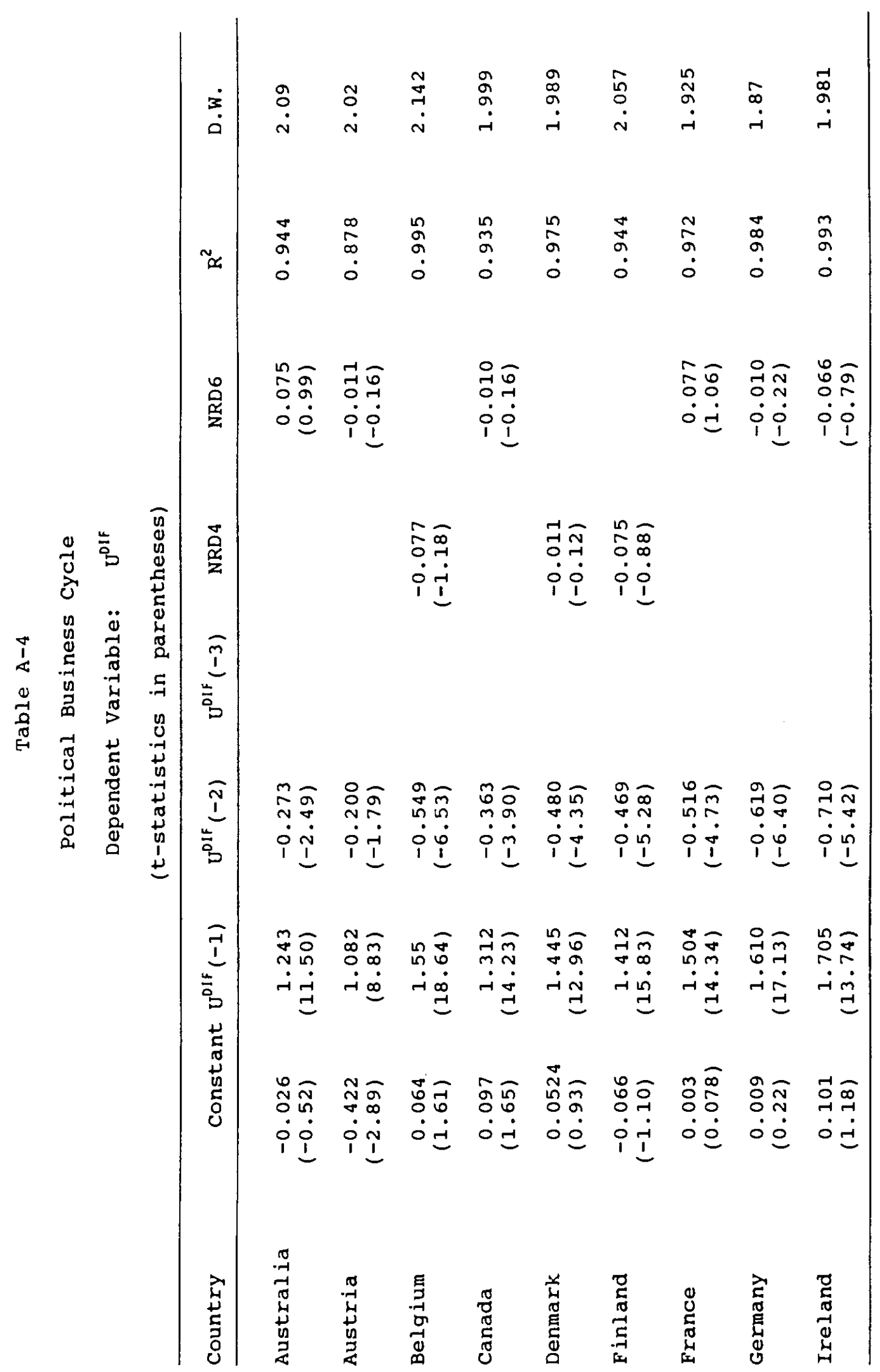




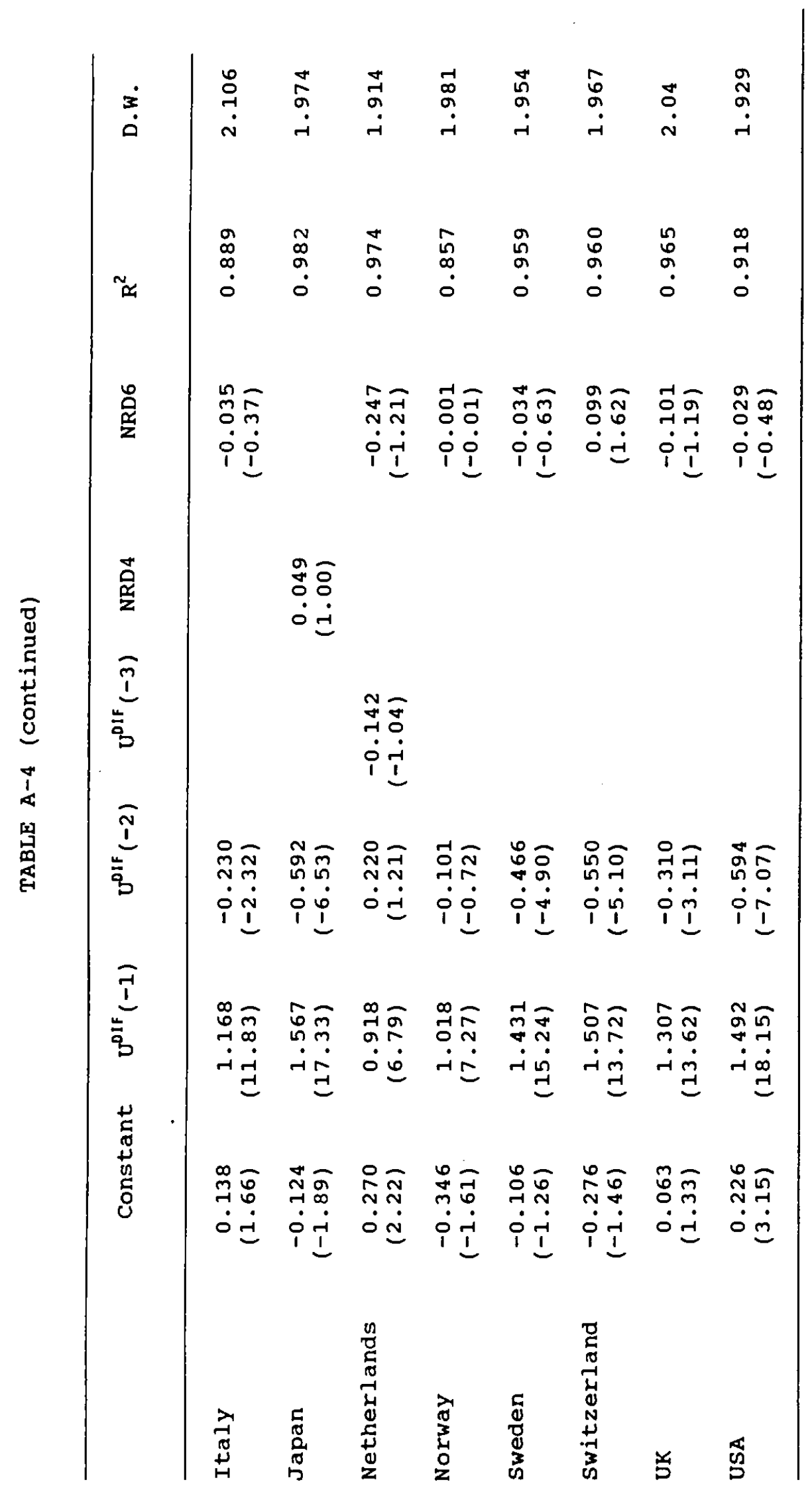


Table A-5

Partisan Theory (HibbsłF

( $t$-statistics in parentheses)

\begin{tabular}{|c|c|c|c|c|c|c|c|}
\hline Country & Const & $\begin{array}{r}D I F \\
u_{\tau-1}\end{array}$ & $\begin{array}{l}D I F \\
u_{t-2}\end{array}$ & \multicolumn{2}{|c|}{$\operatorname{RADM}(-J)$} & $\mathrm{R}^{2}$ & D.W. \\
\hline U.S. & $\begin{array}{r}0.145 \\
(2.42)\end{array}$ & $\begin{array}{r}1.504 \\
(18.93)\end{array}$ & $\begin{array}{l}-0.582 \\
(-7.19)\end{array}$ & $\begin{array}{r}0.027 \\
(0.97)\end{array}$ & $(-2)$ & 0.93 & 1.91 \\
\hline $\mathrm{U} \cdot \mathrm{K}$. & $\begin{array}{r}0.006 \\
(0.17)\end{array}$ & $\begin{array}{r}1.334 \\
(14.61)\end{array}$ & $\begin{array}{l}-0.364 \\
(-3.95)\end{array}$ & $\begin{array}{c}0.052 \\
(1.19)\end{array}$ & $(-1)$ & 0.972 & 1.98 \\
\hline Belgium & $\begin{array}{r}0.036 \\
(1.03)\end{array}$ & $\begin{array}{r}1.541 \\
(18.85)\end{array}$ & $\begin{array}{l}-0.542 \\
(-6.56)\end{array}$ & $\begin{array}{r}0.016 \\
(0.56)\end{array}$ & $(-1)$ & 0.996 & 2.15 \\
\hline Italy & $\begin{array}{r}0.062 \\
(0.92)\end{array}$ & $\begin{array}{r}1.181 \\
(12.40)\end{array}$ & $\begin{array}{l}-0.225 \\
(-2.31)\end{array}$ & $\begin{array}{r}-0.081 \\
(-1.19)\end{array}$ & $(-2)$ & 0.92 & 2.13 \\
\hline Canada & $\begin{array}{c}0.051 \\
(0.82)\end{array}$ & $\begin{array}{r}1.284 \\
(14.17)\end{array}$ & $\begin{array}{l}-0.326 \\
(-3.54)\end{array}$ & $\begin{array}{r}-0.050 \\
(-1.45)\end{array}$ & $(-2)$ & 0.937 & 2.02 \\
\hline Finland & $\begin{array}{l}-0.050 \\
(-0.90)\end{array}$ & $\begin{array}{r}1.370 \\
(15.63)\end{array}$ & $\begin{array}{l}-0.423 \\
(-4.81)\end{array}$ & $\begin{array}{c}0.071 \\
(1.79)\end{array}$ & $(-3)$ & 0.945 & 2.05 \\
\hline Germany* & $\begin{array}{l}-0.034 \\
(-1.07)\end{array}$ & $\begin{array}{r}1.521 \\
(17.75)\end{array}$ & $\begin{array}{l}-0.566 \\
(-6.70)\end{array}$ & $\begin{array}{r}0.120 \\
(3.25)\end{array}$ & $(-1)$ & 0.990 & 1.88 \\
\hline Australia & $\begin{array}{r}0.015 \\
(0.40)\end{array}$ & $\begin{array}{r}1.248 \\
(12.06)\end{array}$ & $\begin{array}{l}-0.275 \\
(-2.64)\end{array}$ & $\begin{array}{c}0.016 \\
(0.42)\end{array}$ & $(-2)$ & 0.951 & 2.08 \\
\hline Austria* & $\begin{array}{l}-0.539 \\
(-3.62)\end{array}$ & $\begin{array}{r}1.037 \\
(8.83)\end{array}$ & $\begin{array}{l}-0.228 \\
(-2.19)\end{array}$ & $\begin{array}{r}0.169 \\
(2.29)\end{array}$ & $(-1)$ & 0.870 & 1.93 \\
\hline Denmark & $\begin{array}{r}0.056 \\
(1.38)\end{array}$ & $\begin{array}{r}1.449 \\
(13.78)\end{array}$ & $\begin{array}{l}-0.483 \\
(-4.64)\end{array}$ & $\begin{array}{r}0.031 \\
(0.79)\end{array}$ & $(-1)$ & 0.975 & 2.05 \\
\hline Netherlands & $\begin{array}{c}0.210 \\
(2.09)\end{array}$ & $\begin{array}{r}0.910 \\
(7.27)\end{array}$ & $\begin{array}{r}0.074 \\
(0.59)\end{array}$ & $\begin{array}{c}0.029 \\
(0.29)\end{array}$ & $(-2)$ & 0.975 & 1.98 \\
\hline Norway & $\begin{array}{l}-0.383 \\
(-1.75)\end{array}$ & $\begin{array}{r}1.008 \\
(7.57)\end{array}$ & $\begin{array}{l}-0.102 \\
(-0.77)\end{array}$ & $\begin{array}{l}-0.004 \\
(-0.07)\end{array}$ & $(-3)$ & 0.856 & 1.96 \\
\hline Ireland & $\begin{array}{r}0.075 \\
(1.00)\end{array}$ & $\begin{array}{r}1.666 \\
(13.90)\end{array}$ & $\begin{array}{l}-0.667 \\
(-5.48)\end{array}$ & $\begin{array}{l}-0.004 \\
(-0.08)\end{array}$ & $(-2)$ & 0.996 & 1.98 \\
\hline Sweden & $\begin{array}{l}-0.178 \\
(-1.93)\end{array}$ & $\begin{array}{r}1.427 \\
(15.22)\end{array}$ & $\begin{array}{l}-0.475 \\
(-5.01)\end{array}$ & $\begin{array}{l}-0.033 \\
(-0.95)\end{array}$ & $(-1)$ & 0.959 & 1.97 \\
\hline France & $\begin{array}{c}0.047 \\
(1.21)\end{array}$ & $\begin{array}{r}1.483 \\
(14.64)\end{array}$ & $\begin{array}{l}-0.492 \\
(-4.73)\end{array}$ & $\begin{array}{r}-0.024 \\
(-0.61)\end{array}$ & $(-2)$ & 0.98 & 1.97 \\
\hline
\end{tabular}

*In order to maintain consistency with the RPT inflation regressions, we used ADM for Germany and Austria. 